NBER WORKING PAPER SERIES

\title{
IMPLEMENTING STRUCTURAL REFORMS IN ABENOMICS: HOW TO REDUCE THE COST OF DOING BUSINESS IN JAPAN
}

\author{
Jamal Ibrahim Haidar \\ Takeo Hoshi \\ Working Paper 21507 \\ http://www.nber.org/papers/w21507
NATIONAL BUREAU OF ECONOMIC RESEARCH
1050 Massachusetts Avenue
Cambridge, MA 02138

August 2015

We thank Koichi Hamada, Dale Jorgenson, Jun Saito, and seminar participants at ESRI (Economic and Social Research Institute, Cabinet Office of Japan) International Conference 2015, Harvard University (Program on U.S.-Japan Relations), and Stanford University (Asia Pacific Research Center) for useful comments. Mary Shiratori provided valuable research assistance. Jamal Ibrahim Haidar acknowledges funding from ENSAE Investissements d'Avenir (ANR-11-IDEX-0003/LabexEcodec/ANR-11-LABX-0047). The remaining errors are our own. Haidar was a member of the World Bank Doing Business team from January 2007 to June 2008 . He received no remuneration from any party for this paper. He has no current affiliation with the Government of Japan or the World Bank. Haidar declares that he has no relevant or material financial interests that relate to the research described in this paper. Hoshi declares that he has no relevant or material financial interests that relate to the research described in this paper. The views expressed herein are those of the authors and do not necessarily reflect the views of the National Bureau of Economic Research.

NBER working papers are circulated for discussion and comment purposes. They have not been peerreviewed or been subject to the review by the NBER Board of Directors that accompanies official NBER publications.

(C) 2015 by Jamal Ibrahim Haidar and Takeo Hoshi. All rights reserved. Short sections of text, not to exceed two paragraphs, may be quoted without explicit permission provided that full credit, including (C) notice, is given to the source. 
Implementing Structural Reforms in Abenomics: How to Reduce the Cost of Doing Business

in Japan

Jamal Ibrahim Haidar and Takeo Hoshi

NBER Working Paper No. 21507

August 2015

JEL No. G38,H25,K22,L51,O43,O53,P16

\begin{abstract}
Improving the environment for business is an important part of the growth strategy of Abenomics. As the goal for this effort, the Abe Administration aims to improve Japan's rank in the World Bank Doing Business Ranking to one of the top three among OECD. This paper clarifies what it takes for Japan to achieve the goal. By looking at details of the World Bank Doing Business ranking, we identify various reforms that Japan could implement to improve the ranking. Then, we classify the reforms into six groups depending on whether the reform requires legal changes and on political resistance that the reform is likely to face. By just doing the reforms that do not require legal changes and are not likely to face strong political opposition, Japan can improve the ranking to 13 th. To be in the top 3, Japan would need to implement all the reforms that are not likely to face strong political resistance. The conclusions, however, are based on the assumption that the conditions in the other countries do not change, which is unrealistic. Thus, Japan would need to carry out all the reforms including those with high political resistance to be among the top three.
\end{abstract}

Jamal Ibrahim Haidar

Paris School of Economics

48 Boulevard Jourdan

75014, Paris

FRANCE

jihaidar@psemail.eu

Takeo Hoshi

Walter H. Shorenstein Asia-Pacific Research Center

Stanford University

Encina Hall - E301

Stanford, CA 94305-6055

and NBER

tkohoshi@stanford.edu 


\section{Introduction}

Abenomics made a good start. After the Liberal Democratic Party (LDP) came back to power in December 2012 and Prime Minister Shinzo Abe announced the new economic policy package dubbed "Abenomics," the economic conditions in Japan improved. More aggressive monetary policy introduced by the Bank of Japan under the leadership of Governor Haruhiko Kuroda seemed to be ending the chronic deflation. The GDP growth was substantially higher than it was expected before the start of Abe administration. ${ }^{1}$ After the consumption tax rate increase by $3 \%$ (from 5\% to $8 \%$ ) on April 1, 2014, however, the economic slowdown was more serious than many expected. In the fall of 2014, the BOJ further expanded the monetary policy to help the ailing economy. Abe Administration also decided to postpone another consumption tax increase (from $8 \%$ to $10 \%$ ) that was planned for October 1, 2015.

Will the slowdown in 2014 turn out to be just a temporary setback for Abenomics? Can Abenomics eventually pull the Japanese economy out of the low growth that has characterized most of the last 20 years? The answer hinges on the success of the growth strategy part of Abenomics, which is referred to as the third arrow. Even if the first two arrows of Abenomics (bold monetary policy and flexible fiscal policy) eventually turn out to be successful, the best they can achieve is to fix the demand shortage and eliminate the output gap. The growth strategy is supposed to address issues for Japan's long-term growth. In order for Japan to escape the longterm stagnation and achieve a higher potential growth, the growth strategy part of Abenomics needs to be successful.

The growth strategy is not a new invention of the Abe administration. Two administrations (led by the Democratic Party of Japan (DPJ)) that immediately preceded the Abe administration also formulated their own growth strategies. In both cases, the prime ministers were forced out before the growth strategy was fully implemented.

There is one thing new about the growth strategy in Abenomics: the planned use of Key Performance Indicators (KPIs). KPIs are assigned to policy goals in the growth strategy and are used to measure the progress. Although many KPIs that have been proposed for Abe's growth strategy are vague as Hoshi (2014) points out, there are a few that are clearly specified. The growth strategy has gone through two revisions, once in June 2014 and the most recent in 2015. In each revision, the status of existing KPIs was reviewed and several new KPIs were added.

This paper takes up a clearly specified KPI and examines what it would take for Japan to achieve the KPI. The KPI that we focus on is the goal of improving Japan's ranking in the World Bank Doing Business Ranking to increase "Japan's international competitiveness." The KPI states "Japan will be one of the top three countries (currently 15th) in the business environment

\footnotetext{
${ }^{1}$ See Buiter and Rahbari (2013), Hausman and Wieland (2014), and Hoshi (2014) for more on Abenomics and its evaluations.
} 
ranking for the developed countries reported by the World Bank in "Doing Business Report" by $2020 ., 2$

Focusing on the business environment makes sense since there is a growing consensus in economic research that the quality of business regulation and the institutions that enforce it are a major determinant of employment creation, private sector development, and economic prosperity. ${ }^{3}$ For example, Haidar (2012) examined the link between regulatory reforms and economic growth in 172 countries using World Bank Doing Business data, and found that each regulatory reform is associated with a 0.15 percent increase in the real GDP growth rate on average. For Japan, Hoshi and Kashyap (2012) list reduction of cost of doing business as one of the important policy options to restart the growth.

This paper clarifies how much reform Japan needs to make to move from its 2015 ranking of $19^{\text {th }}$ (among 31 high income OECD economies) to top three. To do this, we use the information in the 2015 Doing Business Report. Although the KPI was originally based on the 2013 Report, which ranked Japan as $15^{\text {th }}$ among 31 high income OECD economies, Japan's ranking dropped to $19^{\text {th }}$ in the latest (2015) report. Since the government has not changed the original goal of moving to top three in the ranking, we analyze what it takes to achieve the goal based on the latest information.

The paper is organized as follows. The next section studies where Japan is ranked in the 2015 Report in each of the ten areas that the World Bank Doing Business Project looks at to come up with the ranking. We also identify potential regulatory reforms in each area that would improve Japan's ranking. Section 3 then examines the identified regulatory reforms from two perspectives: whether the reform requires any legal changes and whether the reform is likely to face strong political resistance. The reforms that are primarily administrative and are not likely to be political can be accomplished quickly. The reforms that require changes to prevailing laws and/or are likely to be political would take more time. Section 4 concludes.

\section{Japan in the World Bank Doing Business Ranking: Current Standing and Potential Reforms}

Japan is ranked $29^{\text {th }}$ overall among the 189 economies covered by the World Bank 2015 Doing Business Project, but $19^{\text {th }}$ out of the 31 high income OECD economies. ${ }^{4}$ The ranking is compiled

\footnotetext{
${ }^{2}$ Quoted from the original growth strategy documents. The ranking $\left(15^{\text {th }}\right.$ among OECD) is from the 2013 ranking. Japan remained $15^{\text {th }}$ in the 2014 ranking but slipped to $19^{\text {th }}$ in the 2015 ranking. Throughout this paper, we use data from the World Bank Doing Business 2015. The data cut-off date for the 2015 Doing Business ranking was June, 1 2014.

${ }^{3}$ See Blanchard and Portugal (1998), Holmes (1998), Besley and Burgess (2004), Alesina et al. (2005), Klapper et al. (2006), Ciccone and Papaionnou (2007), Dabla-Norris et al. (2008), Klapper and Love (2010), and Haidar (2012) among others

${ }^{4}$ World Bank Doing Business 2015 Report.
} 
by the World Bank every year by looking at ten areas of doing business, many of which are critically influenced by government regulations. Japan is ahead of other countries in some areas such as protecting minority investors, trading across borders, enforcing contracts, and resolving insolvency. As shown in Table 1, Japan is ranked $17^{\text {th }}, 14^{\text {th }}, 16^{\text {th }}$, and $2^{\text {nd }}$ among OECD economies respectively in these areas. ${ }^{5}$ Japan can do better, however, in the other areas. In the ease of starting a business, getting credit, registering property, and paying taxes, Japan is ranked $27^{\text {th }}, 22^{\text {nd }}, 23^{\text {rd }}$, and $30^{\text {th }}$ among the 31 OECD economies respectively. This section reviews Japan's ranking in each of the ten areas and identifies some regulatory reforms that Japan can implement to improve its ranking.

\section{2-1. Starting a business}

Japan currently ranks $27^{\text {th }}$ out of the 31 OECD economies on the ease of starting a business. It is estimated to cost $7.5 \%$ of Japan's income per capita (of 2013) to formally start a business in Tokyo. The process takes 8 procedures and requires 11 days in Tokyo. In comparison, an entrepreneur can start a business by following just one procedure, in a half day, and at a cost of $0.3 \%$ of income per capita in New Zealand. Similarly, starting a business requires only 3 procedures and 2.5 days in Australia. It costs only $0.4 \%$ of income per capita to start a business in Canada.

Table A1 in Appendix 1 shows the details of the information collected by the World Bank to evaluate the procedures, time, and costs required to start a business in Tokyo. There are several reforms that Japan can implement to reduce the number of steps, the monetary cost, and the time to start a business in Japan. The major ones are the following four.

- Eliminate the requirement for a company seal (reform 1)

- Make business registration administrative rather than judicial (reform 2)

- Create one-stop shop for business registration (reform 3)

- Cut registration fees (reform 4)

Eliminate the requirement for a company seal: Currently, an entrepreneur is required to make a company seal and register it. These two procedures take about 4 days. The company seal is required, per Article 20 of the Commercial Registration Act. The associated fee is about $¥ 10,000$ for machine-carved seal or $¥ 20,000$ for hand-carved seal. The entrepreneur or a company representative must register the company seal and obtain the certificate of seal registration from the Ward office in person. The certificate then must be submitted to the Legal Affairs Bureau at the Ministry of Justice. The fee is approximately $¥ 400$ per certificate of seal registration but

\footnotetext{
${ }^{5}$ Throughout the paper, we refer to OECD as the set of 31 OECD high income countries, not to the set of 34 OECD members. The latter (34 member) group includes Chile, Mexico, and Turkey.
} 
varies from ward to ward. The requirement is a legacy of the old business practice where a seal symbolized the legal identity of a business and authenticated all its contracts.

Make business registration administrative rather than judicial: To apply for registration, an entrepreneur submits a duly completed application form, along with supporting documents including the certificate of seal registration and the Articles of Incorporation to the Legal Affairs Bureau headquarter or any of its branch offices in major cities (Tokyo, Yokohama, Osaka, Nagoya, Kobe, and Fukuoka). Once the filed documents are reviewed and approved, the company applies for the issuance of a company registration certificate. Normally, a judicial scrivener completes the registration on behalf of the company. The whole process takes 4 days in Japan. The 2004 amendment to the Commercial Registration Regulations has made it possible for entrepreneurs to submit company registration applications online, but the time this legal process takes has not been shortened. Japan can reduce the time for business registration by making it a simple administrative process rather than judicial process. This changeover is straightforward and has been done in many countries less developed than Japan, including Serbia, Uganda, Bulgaria, and Honduras.

Create one-stop shop for business registration: Currently, the eight procedures that must be completed to start a business in Japan require an entrepreneur to visit many regulators including the Ward Office (to obtain the certificate of seal registration), Ministry of Justice, District Tax Office, Municipality, Labor Standards Inspection Office, Japan Pension Service, and Public Employment Security Office. Cumbersome registration procedures mean more hassle for entrepreneurs. Creating one-stop shops for company registration has been a popular reform over the last decade in many countries. For example, Portugal combined company, tax and social security registrations in one building. A one-stop shop in Tokyo would allow entrepreneurs in Japan to register with all the above agencies in a single visit and can open their businesses faster.

Cut registration fees: It currently costs $0.7 \%$ of the official stated capital or $¥ 60,000$, whichever is higher, to register the company at the Legal Affairs Bureau of the Ministry of Justice in Japan. This amount $(¥ 60,000)$ is equivalent to $7 \%$ of Japan’s income per capita. The cost in Denmark is only $0.2 \%$ of its income per capita. Registration fees account for the bulk of the direct monetary cost to start a business in Japan. By reducing registration fees to $¥ 1,700(0.2 \%$ of income per capita: level of Denmark), Japan can substantially cut the cost to start a business.

Many authors have taken interest in the impact of business entry reforms. For example, Branstetter et al. (2014) evaluated the consequences of a recent regulatory reform in Portugal, which substantially reduced the cost of firm entry. They found that the reform resulted in increased firm formation and employment. Also, Bruhn (2011) estimated the economic effects of a reform that simplified business entry regulation in Mexico. Using micro-level data, she found that the reform increased the number of registered businesses by $5 \% .{ }^{6}$

\footnotetext{
${ }^{6}$ Djankov (2009) included an earlier literature survey on the effects of making business entry easier.
} 


\section{2-2. Dealing with construction permits}

Japan stands at $19^{\text {th }}$ out of 31 OECD economies on the ease of dealing with construction permits. This indicator measures what it takes to comply with formalities to build a warehouse in Japan. These formalities currently require 12 procedures compared to 7 in Sweden, 197 days compared to 29 days in Korea, ${ }^{7}$ and direct monetary cost of $0.6 \%$ of warehouse value compared to $0.1 \%$ in Slovak Republic. Instead of making the process cheaper, Japan made dealing with construction permits more costly by increasing inspection fees in 2012.

It would not be acceptable to do away with construction permits completely because sound regulation of construction helps protect the public from faulty building practices. Moreover, enhancing public safety, well-functioning building permit and inspection system can also strengthen property rights and contribute to the process of capital formation. ${ }^{8}$

Table A2 shows the details of the information collected by the World Bank to evaluate the procedures, time, and costs associated with dealing with construction permits in Tokyo. Japan can reduce the cost for entrepreneurs to deal with construction permits without compromising building safety. The major reform measures to improve the ranking in the ease of dealing with construction permits are:

- Reduce number of procedures to get a construction permit (reform 5)

- $\quad$ Reduce the time to issue a construction permit(reform 6)

Reduce number of procedures to get a construction permit: A company in Japan must complete 12 steps to legally build a warehouse, according to the World Bank Doing Business database through information collected from experts in construction licensing, including architects, civil engineers, construction lawyers, construction firms, utility service providers and public officials who deal with building regulations. These procedures include acquiring permits/consents from local authority, neighborhood, Building Department of Government of Tokyo, Labor Control Office, Japan Building Center, and Land and Building Registry.

Some of these procedures are redundant and can be merged with other ones. For example, currently the builder needs two separate procedures to receive intermediate and final inspections from Japan Building Center and another procedure to obtain completion certificate.

Japan can benefit from the experience of various OECD countries that reduced the number of construction licenses. In Germany some simple construction projects no longer require a permit. Instead, the builder only notifies the municipality when construction starts. Inspectors show up at the site once the project has begun. After this reform the time to comply with licensing and permit requirements fell from 165 days to 133. In France the number of

\footnotetext{
${ }^{7}$ Korea stands at $3^{\text {rd }}$ respectively out of 31 OECD economies on the ease of dealing with construction permits.

${ }^{8}$ World Bank (2013)
} 
licenses required for construction projects was reduced from 11 to 9 . In Sweden, only 9 procedures are required, too. Elsewhere in Europe, Spain no longer requires an installation license on top of the building license, cutting the number of procedures by one.

Reduce the time to issue a construction permit: Japan can reduce the number of days to deal with construction permits by (1) introducing statutory time limits and (2) scaling back inspections for small construction projects. The procedures to get approvals from the Japan Building Center and Labor Control Office account for the bulk of time required -- 130 out of 197 days -- to deal with construction permits. Two other procedures to get approvals from Japan Building Center and Water and Sewage Services add another 45 days. Japan can reduce the number of days to deal with construction permits by introducing statutory time limits.

In France, the average amount of time to get a construction permit was reduced by one month by requiring the building inspectorate to visit and issue a declaration of work completion within 3 months. In addition, the government can introduce "silence is consent" rules for issuing building licenses. For example, Spain set the maximum time for approval at 90 days and adopted the "silence is consent" rule at the same time. Similarly, the Netherlands introduced a 45-day limit.

Another reform that will reduce the time it takes to issue a permit is to adjust inspections to the size and nature of the project. Smaller projects could receive less scrutiny, lowering compliance costs and allowing regulators to focus their energy on more complex projects. Korea implemented such reform in 2006. It exempted small construction projects from the requirement to apply for an advance building permit.

\section{2-3. Getting electricity}

Japan currently ranks $9^{\text {th }}$ on the Ease of Getting Electricity indicator. This indicator tracks the number of procedures, the time, and the direct monetary cost necessary for a business to obtain a permanent electricity connection for a newly constructed warehouse. Getting access to electricity to a warehouse in Japan requires 3 procedures, takes 105 days although it costs a negligible amount of money. It takes only 17, 18, and 22 days in Germany, Korea, and Iceland, respectively. ${ }^{9}$

Table A3 shows the details of the information collected by the World Bank to evaluate the procedures, time, and costs associated with obtaining access to electricity in Tokyo. While Japan performs well on the number of procedures and the direct monetary cost, it can implement the following reform to improve its ranking:

- Reduce the number of days it takes to get electricity by 80 days by improving efficiency of the process (reform 7)

\footnotetext{
${ }^{9}$ Germany, Korea, and Iceland currently rank $2^{\text {nd }}, 1^{\text {st }}$, and $5^{\text {th }}$, respectively, on the Ease of Getting Electricity indicator.
} 
Reduce the number of days it takes to get electricity by 80 days by improving efficiency of the process: Japan can reduce the time between submitting application to TEPCO and getting connection works. After an initial contact with TEPCO on construction date and effective date of contract, it currently takes 93 days before electricity connection works start. After an average of 93 days of waiting, TEPCO takes 11 more days to carry out connection works and install a meter. ${ }^{10}$

Examples from the rest of the world show that it is possible to increase the efficiency of utilities' internal processes and reduce the electricity connection delays. Malaysia, Mexico, and Turkey made getting electricity easier by improving communications with contractors, introducing electronic document management systems and increasing staff and resources for inspections. In Burundi the electricity utility Regideso ended its monopoly on the sale of transformers and other equipment needed for electricity connections. Since June 2012 the change has decreased the time to obtain a connection by 30 days because customers can now import materials instead of buying them from Regideso if the materials are not in the company's stock. The utility also opened a center that combines all the internal services of the utility involving new connections. Mexico's electricity utility, Comisión Federal de Electricidad, streamlined the process for obtaining electricity, offered training to contractors and implemented a geographic information system (GIS) that maps the electricity network. This commitment has paid off: the time to obtain a new electricity connection in Mexico City dropped from291 days in 2009 to 85 in 2013.

\section{2-4. Registering property}

Japan is currently ranked $23^{\text {rd }}$ on the ease of registering property. Doing Business records the full sequence of procedures necessary for a business to purchase property from another business and transfer the property title to the buyer's name. The transaction is considered complete when it is opposable to third parties and when the buyer can use the property, use it as collateral for a bank loan or resell it.

Registering property in Tokyo requires 6 procedures, takes 13 days and costs $5.8 \%$ of the property value. More than 30 countries made it easier to register property since 2006. Japan was not one of them, although its property registration process is relatively complicated compared to other OECD countries. It is easier to register property in New Zealand than anywhere else in the world. The entire process can be completed in 2 online procedures at a monetary cost of $0.1 \%$ of the property value. Lawyers certify land transfer documents for their clients and submit them electronically for registration. Confirmation is returned within minutes. In general, the cost of

\footnotetext{
${ }^{10}$ Since the data were collected in 2013 and 2014, one might wonder if the long delays in Japan may reflect TEPCO's troubles after its nuclear power plant accidents following the earthquake and Tsunami of March 2011. But it is not the case. The delay was already long before 2011. For example, in the 2010 ranking, the total number of days it typically took from application to the end of connection works were 105 days.
} 
registering property is lower by $26 \%$ on average in common law compared with civil law countries, a result largely driven by differences in non-notary costs of registering property. ${ }^{11}$

Table A4 shows the details of the information collected by the World Bank to evaluate the procedures, time, and costs associated with registering property in Tokyo. To improve its ranking in this category, Japan can:

- $\quad$ Reduce the time to register property by 7 days by introducing fast-track procedures (reform 8)

- Combine and eliminate some procedures for registering property (reform 9)

- Lower property registration fees (reform 10)

Reduce the time to register property by 7 days by introducing fast-track procedures: An entrepreneur currently spends 7-10 days to file an application for registration at the Legal Affairs Bureau. The Legal Affairs Bureau registers the title under the name of the new owner. As registration is a requirement for perfection against third parties, reviewing the certified copy of the real property registry is generally sufficient for identifying any existing encumbrances over the real property. The parties may apply for registration by themselves. However, because of the complexity of filing, usually they retain a judicial scribe for registration.

The Legal Affairs Bureau may be in need of some structural reforms to reduce their respective delays but such reforms might require long-term efforts. In order to speed up registration in the meantime, the Legal Affairs Bureau could offer clients a choice of expedited procedures: pay a slightly higher fee and the registration is completed faster. It could offer expedited processing of 1-2 days, instead of waiting 7-10 days. Cases would be prioritized in a transparent manner, and those that prefer not to wait would be given an official way to speed up the process by 8-9 days in total. This type of scheme is offered in a number of countries around the world, from Singapore to Netherlands. Singapore introduced an online fast-track registration process for single transfers, enabling property transfers to be completed in one day. Simultaneously, the Legal Affairs Bureau can work on further reforms to reduce time for everyone - for example, by adopting shorter time-limits to process applications.

Combine and eliminate some procedures for registering property: Each party of the transaction must obtain a corporate registry certificate that has been issued within 3 months before the application. It can be obtained from a corporate registry office where the party is registered. The cost is $¥ 600$ per copy ( $¥ 480$ if obtained online). The seller also must obtain a certificate of its seal used for execution of the registration documents (issued within 3 months). It can be obtained from the Legal Affairs Bureau. The cost is $¥ 450$ per copy ( $¥ 390$ if obtained online). These two procedures can be combined, especially as the seller also needs to obtain yet another certificate

\footnotetext{
${ }^{11}$ Amin and Haidar (2012)
} 
of evaluation for property tax at a local tax office. Japan can also cut the requirement to obtain stamps for stamp duty at a post office. Instead, the payment, if needed, can be made at the Legal Affairs Bureau.

Lower property registration fees: Currently, an entrepreneur in Tokyo must pay a registration and license tax of $1.75 \%$ of property value and a property acquisition tax of $4 \%$ of property value. The cost to register could be reduced significantly by replacing these taxes by a fixed fee. High percentage-based taxes may lead some entrepreneurs to resort to underreporting their property value to avoid paying the full amount or to avoid registration completely. As a result of such reform, Japan would be able to make the cost of registering property as low as $0.1 \%$ of property value, as in New Zealand, which is ranked $2^{\text {nd }}$ in this category.

Many governments have reduced the cost of property registration by establishing a low fixed registration fee rather than charging entrepreneurs a percentage of the property value. In 2005, Slovakia abolished its 3\% real estate transfer tax and set a low fixed fee for expedited registration at 8,000 Koruny (\$286). In 2007, Egypt and Poland adopted similar reforms. These reforms also ended up reducing fraud in reporting the value of property and increased tax revenues. Six months after Egypt replaced its 5.8\% registration fee with a fixed fee of 2,000 Egyptian pounds (\$323), the revenues rose by $39 \%{ }^{12}$

\section{2-5. Getting credit}

Two types of frameworks can facilitate access to credit and improve its allocation: credit information systems and laws on collateral and bankruptcy. Credit information systems enable lenders to view a potential borrower's financial history (positive or negative). And they permit borrowers to establish a good credit history that allows an easier access to credit. Sound collateral laws enable businesses to pledge their assets as security to raise funds. Past research found strong creditors' rights specified in collateral and bankruptcy laws are associated with higher ratios of private sector credit to GDP. ${ }^{13}$

The World Bank Doing Business ease of getting credit index assesses the sharing of credit information and the legal rights of borrowers and lenders with respect to secured transactions using two indices. The depth of credit information index examines rules and practices affecting the coverage, scope and accessibility of credit information available through public credit registries and private credit bureaus. The strength of legal rights index measures whether certain features that facilitate lending exist within the collateral and bankruptcy laws of the country.

How well do the credit information system and laws on collateral and bankruptcy in Japan facilitate the access to credit? Japan has a score of 6 (out of 8) on the depth of credit

\footnotetext{
${ }^{12}$ Haidar (2007 and 2008)
}

${ }^{13}$ Djankov et al (2007) 
information index and a score of 4 (out of 12) on the strength of legal rights index. Higher scores indicate more credit information and stronger legal rights for borrowers and lenders. Japan is ranked $22^{\text {nd }}$ among OECD economies on the ease of getting credit.

Table A5 shows the details of the information collected by the World Bank to evaluate the strength of credit reporting systems and the effectiveness of collateral and bankruptcy laws in facilitating lending in Tokyo. To improve its ranking on the ease of getting credit indicator, Japan can:

- Create a unified legal framework for secured transactions including creation, publicity and enforcement of security interests in movable assets (reform 11)

- Create a collateral registry in which all functional equivalents can be registered (reform 12)

- Reform bankruptcy law (reform 13)

- Establish a public credit registry for corporations (reform 14)

Create a unified legal framework for secured transactions including creation, publicity and enforcement of security interests in movable assets: Japan can improve collateral laws to make it easier for businesses to use their assets, especially movables, to secure credits. In what is considered to be the best practice, the businesses would be allowed to grant a non-possessory security right in a single category of movable assets (such as "machinery" or "inventory") without requiring a specific description of the collateral. Security right also should extend to future or after-acquired assets and to the products, proceeds or replacements of original assets automatically. This reform would increase the strength of legal rights index by 3 points.

Create a collateral registry in which all functional equivalents can be registered: Japan can improve the system of registering collateral by creating a collateral registry in which all functional equivalents to security interests in movable assets (fiduciary transfer of title, financial leases, assignment or transfer of receivables, and sales with retention of title). The collateral registry should cover both incorporated and non-incorporated businesses, unified geographically, and with an electronic database indexed by debtor's names. The collateral registry should also allow secured creditors to register, search, amend or cancel security interests online. This reform would increase the strength of legal rights index by another 3 points.

Reform Bankruptcy law: Japan can also improve the security rights of lenders in courtsupervised restructuring by changing the bankruptcy law. More concretely, Japan can introduce automatic stay for creditors in court-supervised reorganizations (Corporate Reorganization or Civil Rehabilitation). Japan can also allow secured creditors to be paid first even before tax claims and employee claims when a business is liquidated. This reform would increase the strength of legal rights index by additional 2 points. 
Establish a public credit registry for corporations: Japan has private sector credit bureaus that collect and distribute credit information on individuals, but does not have those for credit information of corporations. To fill the gap, the government can create a public credit registry that collects and distributes credit information on corporations. With this change, the depth of credit information index for Japan will rise by 1 point. If Japan's credit bureaus also start providing credit scores as a value-added service to help banks and financial institutions to assess the creditworthiness of borrowers, that would increase the index by another point and bring it up to the full score (8/8). However, it is unclear what an effective government policy to achieve this can be.

By completing these 4 reforms, Japan would achieve full scores in strength of legal rights index (12/12) and increase depth of credit information index to $7 / 8$. This would make Japan jump to the second among the OECD countries (and in the world) on the ease of getting credit.

Various recent studies have focused on the importance of creditor protection and credit information sharing. For example, Djankov et al. (2007) found that both creditor protection through the legal system and information sharing institutions are associated with higher ratios of private credit to GDP. In addition, Doblas-Madrid and Minetti (2013) investigated the impact of lenders' information sharing on firms' performance in the credit market using rich contract-level data from a U.S. credit bureau. They found that information sharing reduces contract delinquencies and defaults, especially when firms are informationally-opaque. ${ }^{14}$

\section{2-6. Protecting minority investors}

The "protecting minority investors" indicator measures the transparency of related-party transactions, liability for self-dealing, and shareholders' ability to sue officers and directors for misconducts. Japan currently ranks $17^{\text {th }}$ among the OECD countries on the strength of investor protection index. It scores $7 / 10$ on the extent of disclosure index, $6 / 10$ on the extent of director liability index, 8/10 on the ease of shareholder suits index, 7/10 on the extent of conflict of interest regulation index, $7 / 10.5$ on the extent of shareholder rights index, 4.5/10.5 on the strength of governance structure index, and 4.5/9 on the extent of corporate transparency index. One of the most important potential problems in corporate governance is self-dealing: the use of corporate assets by company insiders for personal gain. Related-party transactions are the most common example. High ownership concentration and informal business relations can create the perfect environment for such transactions, which allow controlling shareholders to profit at the expense of the company's financial health. Company assets may be sold at an excessively low price to controlling shareholders, assets may be bought at an inflated price from controlling

\footnotetext{
${ }^{14}$ See also Houston et al (2010), Haselmann et al. (2010), and Vig (2013) for related studies.
} 
shareholders, or company loans are given to controlling shareholders on terms far better than the arms-length offers.

Economies with strong protections of minority investors would have clear and detailed rules on disclosure and duties for corporate directors. They would also have well-functioning court system to allow minority shareholders to obtain judgments within reasonable time.

Empirical research shows that the level of investor protection matters for cross-country differences in income growth: countries with stronger protections tend to grow faster than those with poor investor protections. ${ }^{15}$ Moreover, stricter regulation against self-dealing is associated with larger equity investment and less concentrated ownership. ${ }^{16}$ This is in line with the view that stronger legal protections make minority investors more confident about their investments and reduce the need for concentrated ownership to mitigate weaknesses in corporate governance.

Table A6 shows the details of the information collected by the World Bank to evaluate the strength of minority shareholders protections in Tokyo. To further strengthen investor protections, Japan can:

- Increase disclosure requirements (reform 15)

- Increase directors' liability (reform 16)

- Allow the plaintiff of a shareholder suit to request categories of documents without identifying specific ones (reform 17)

- Strengthen governance structure (reform 18)

- Enhance corporate transparency (reform 19)

- Improve shareholder rights (reform 20)

Increase disclosure requirements: Japan currently scores $7 / 10$ in the extent of disclosure requirements. By implementing the following three reforms, Japan can improve the score to perfect 10/10. First, Japan can require a resolution at both a board meeting and a general shareholders meeting to approve business transactions that entail a conflict of interest of a director and majority shareholders. Currently a resolution at the board level is sufficient. Second, a review by an external body for such transaction can be required before it takes place. Third, Japan can require immediate disclosure, to the public and/or shareholders, of transactions that entail a conflict of interest.

Increase directors' liability: Japan currently scores $6 / 10$ on the extent of director liability. Japan can improve the score to $10 / 10$ by implementing the following three reforms. First, Japan can

\footnotetext{
${ }^{15}$ Haidar (2009)

${ }^{16}$ Djankov et al (2008)
} 
give the judicial system the power to void a business transaction if the transaction is deemed unfair to minority shareholders or entails a conflict of interest. Second, directors can be required to pay the damages caused to the company and also repay the profit made from self-dealing. Third, a director at fault can be punished by fines and imprisonment.

Allow the plaintiff of a shareholder suit to request categories of documents without identifying specific ones: Japan already scores $8 / 10$ on shareholder suits, but it can improve the score to $9 / 10$ by allowing the plaintiff to request categories of documents from the corporate defendant without identifying specific ones.

Strengthen governance structure: Japan scores $4.5 / 10.5$ on the strength of governance structure index. It can improve its score to $10.5 / 10.5$ by implementing the following four reforms. First, Japan can bar CEOs from also serving as chairs of the board of directors. Second, it can require companies to have separate audit committees. Third, Japan can ask a potential acquirer to make a tender offer to all shareholders upon acquiring $50 \%$ of a company. Fourth, it can limit crossshareholding between 2 independent companies to $10 \%$ of outstanding shares.

Enhance corporate transparency: Japan scores $4.5 / 9$ on the extent of corporate transparency index. It can improve to $7.5 / 9$ by implementing the following two reforms. First, Japan can require ownership stakes representing $10 \%$ to be disclosed. Second, it can make obligatory the disclosure of the compensation of individual managers.

Improve shareholder rights: Japan scores $7.5 / 10.5$ on the extent of shareholder rights index. It can improve to $10.5 / 10.5$ by (i) allowing shareholders to amend company bylaws or statutes with a simple majority and (ii) granting shareholders automatic subscription rights on new shares.

\section{2-7. Paying taxes}

The Doing Business paying taxes indicator measures the time and cost associated with paying all taxes and other mandatory payments as required by government. Japan is ranked 30 out of 31 in OECD, making this the lowest performing area for Japan. On average, a firm makes 14 tax payments a year, spends 330 hours a year preparing, filing, and paying taxes and pays $51.3 \%$ of profit as taxes.

Efficient tax administration can help encourage businesses to become formally registered thereby expanding the tax base and increase tax revenues. Administration that is unfair and capricious will bring the tax system into disrepute and weaken the legitimacy of government. Overly complicated tax systems are associated with high tax evasion. High tax compliance costs are associated with larger informal sectors, more corruption and less investment. Economies with simple, well-designed tax systems are able to help the growth of businesses and, ultimately, the growth of overall investment and employment. ${ }^{17}$ Also, measures of tax complexity have a

\footnotetext{
${ }^{17}$ Djankov et al (2010)
} 
significant inhibiting effect on the presence of FDI for a country pair: a $10 \%$ reduction in tax complexity is comparable to a one percentage point reduction in effective corporate tax rates. ${ }^{18}$ In addition, a cut in the corporate tax rate by 10 percentage points could raise the annual growth rate of an economy by one to two percentage points. ${ }^{19}$

Table A7 shows the details of the information collected by the World Bank to evaluate what a typical startup company in Tokyo needs to do to pay all the required taxes and contributions. ${ }^{20}$ Looking at the table, Japan can implement two reforms to improve its ranking on the ease of paying taxes.

- Reduce number of payments (reform 21)

- Reduce corporate profit tax rate (reform 22)

Reduce number of payments: While a company needs to make 3 tax payments in Hong Kong, 4 in Norway, and 5 in Singapore, it has to make 14 payments in Japan. In Norway, the 4 payments are corporate income tax, social security contribution, value added tax, and fuel tax. In addition to these 4 payments, a company in Tokyo must also pay inhabitants tax, a depreciable fixed assets tax, a fixed assets tax on land and building, employer paid employment and health insurance premia, real property acquisition tax (for building expansion), business premises tax (on floor space), stamp tax (on contracts for land sale and building expansion), registration and license tax, automobile tax, and automobile tonnage tax.

Multiple taxations, where the same tax base is subject to more than one tax treatments, appear to be making tax compliance cumbersome for taxpayers in Japan. Multiple taxations increase the cost of doing business for firms because it increases the number of payments and compliance time. Different forms have to be filled out, often applying different methods for calculating the tax.

Consolidating taxes would be a worthwhile reform. Tax offices can then distribute the revenues among government agencies. Slovakia did just that: its single social contribution tax funds health insurance, sickness insurance, old age pensions, disability insurance, unemployment benefits, injury insurance, guarantee insurance and reserve fund contributions. In many countries social security agencies would be reluctant to part with their powers, especially if there is a chance that the central tax office will not give them their share of revenues. To gain their trust, a formulaic allocation of revenues can be introduced so that there is little room for discretion.

\footnotetext{
${ }^{18}$ Lawless (2013)

${ }^{19}$ Lee and Gordon (2005)

${ }^{20} \mathrm{We}$ believe that the number of fuel tax payments reported in table (1) is not correct. The fuel tax is included in gas price that is paid at pump. Thus, companies do not pay fuel tax separately from their payment for fuel.
} 
Fifty-five economies have one tax per tax base. This keeps things simple. Having more types of taxes requires more interactions between businesses and tax agencies. It also complicates tax compliance.

Businesses in Korea no longer need to calculate numerous taxes on the same base. Starting with the 2010 tax year, property taxes and city planning taxes are being merged with other taxes. And, thanks to an effort aimed at unifying social security laws and administrations, businesses can now file and pay 4 labor taxes and contributions in a single payment. This reform freed businesses from the requirement to file additional returns and bear additional tax compliance costs.

Canada has harmonized and simplified its tax system. Beginning in the 2010 tax year, businesses are subject only to the federal harmonized sales tax, which replaced the former federal goods and services tax and provincial sales tax.

The time required to pay taxes estimates the number of hours it takes a typical company to gather data, analyze accounting information to highlight sensitive tax items, calculate tax liability, and submit payments. The process is estimated to take 330 hours in Japan but only 63 hours in Switzerland. ${ }^{21}$ By reducing the number of payments, Japan can also reduce the number of hours it takes a company to pay taxes.

More specifically, the following reform can reduce the number of taxes. First, all the taxes levied on corporate profits (corporate income tax, enterprise tax, inhabitants tax, and restoration surtax) are combined into one. Similarly, all the contributions that are based on gross salaries that the firm pays to its employees (employer contributions to welfare pension insurance, health insurance, workmen's accident insurance, employment insurance, and child allowance) are combined into one. All the taxes on fixed assets (depreciable fixed assets tax, fixed assets tax, city planning tax, automobile tax, and automobile tonnage tax) are also combined into one. Two taxes for building expansion (real property acquisition tax and registration and license tax) are combined into one. Finally, the reform eliminates the stamp tax altogether. Then, the combined corporate income tax and the combined employee contribution are made to be collected at the same time once a year. In addition, the corporation will be paying taxes just three more times (combined tax on fixed assets, combined tax for building expansion, and the value added tax). Thus, the total number of tax payments will be reduced to four. We do not expect the preparation time for tax to be reduced proportionally. Somewhat arbitrarily, we assume the reform will reduce the preparation time for corporate income tax and employee contribution to health insurance by $33 \%$ because they are now collected at the same time, but the preparation time for the value added tax does not change. Under this assumption, the total time the firm spends to pay taxes will be reduced from 330 hours to 233 hours.

\footnotetext{
${ }^{21}$ For comparability purpose, the Doing Business Project takes a standard case/company in each country for each area. In estimating the time it takes to pay taxes, the standardized company is assumed to have a turnover of 1050 times income per capita.
} 
Reduce corporate profit tax rate: The total tax rate (as \% of profit) is $21 \%$ in Canada and $25.9 \%$ in Ireland but $51.2 \%$ in Japan. While the marginal statutory corporate income tax rate is 3.9\% in Canada and $12.4 \%$ in Ireland, it is $28.9 \%$ in Japan. And, the labor tax and contributions account for $12.5 \%$ in Canada, $12.1 \%$ in Ireland, and $18.1 \%$ in Japan. Japan could benefit from reducing the total tax rate.

Specifically, we examine the impact of the reform that ends up reducing the total effective tax rate by $20 \%$ to $31.2 \%$ on the ranking. The reform is much more drastic than that currently planned by the Abe administration. The government aims to reduce the effective tax rate by more than $5 \%$ in several years and by more than $10 \%$ in the long run. As the first step, the Cabinet tax reform plan for FY2015 calls for $2.51 \%$ reduction of the effective corporate tax rate for FY2015 and another $3.29 \%$ for FY2016. ${ }^{22}$

\section{2-8. Trading across borders}

Japan is ranked $14^{\text {th }}$ out of 31 on the Doing Business trading across borders indicator. This indicator measures the time and cost associated with exporting and importing a standardized cargo of goods by sea transport. The time and cost necessary to complete every official procedure for exporting and importing the goods are recorded. All documents needed by the trader to export or import the goods across the border are also recorded. In France and Ireland, only two documents (the bill of lading and customs declaration) are required to export or import. But, in Japan, one more document (the commercial invoice) is required to export and three more documents (cargo dispatch document, commercial invoice, and packing list) are required to import. And, while it takes 11 days to comply with all the procedures required to export or import goods in Japan, it takes only 6 days to comply with the procedures required to export and 5 days to comply with the procedures required to import in Denmark, United States, and Estonia. The cost associated with procedures required to export (import) is $29 \%$ (45\%) lower in Hong Kong than in Japan. ${ }^{23}$

Table A8 shows the details of the information collected by the World Bank to evaluate the number of documents, days, and costs required by a typical company in Tokyo to import and export. To improve its ranking on the ease of trading across borders, Japan can:

- Allow electronic submission and processing (reform 23)

- Link agencies through an electronic single window (reform 24)

\footnotetext{
${ }^{22}$ Ministry of Finance Japan (2015) Tax Reform (Main Points). (http://www.mof.go.jp/english/tax_policy/tax_reform/fy2015/tax2015a.pdf, accessed on April 12, 2015).

${ }^{23}$ While trade facilitation does improve as the country size becomes smaller, the relationship between country size and trade facilitation does not appear to be driven by the fact that small countries trade more as a proportion of their GDP than the large countries. See Amin and Haidar (2014) for details.
} 
- Use risk-based inspections (reform 25)

- Improve transparency in trade regulation (reform 26)

Allow electronic submission and processing: Electronic systems for filing, transferring, processing, and exchanging customs information have become an important tool for managing flows of information in complex trading systems. The newest web-based systems can allow Japanese exporters and importers to submit their documents from anywhere and to pay duties online. Japan can update its regulatory framework to allow exporters and importers to take advantage of the new information technologies. Over the past 9 years, 119 economies have introduced or improved such systems. Today traders can submit all trade documents electronically in more than half of OECD high-income economies with no need to provide hard copies. For example, France speeded up and simplified its customs clearance procedures by introducing an electronic customs declaration and eliminating the need to submit certain documents. The Netherlands made importing easier by introducing a new web-based system for cargo release at the port terminals in Rotterdam. Spain also expanded the use of electronic submission of customs declarations.

Link agencies through an electronic single window: Increasingly, economies are going a step further by virtually linking not only traders and customs but all agencies involved in trade and transport through an electronic single-window system. In what is considered the best practice today, such a system allows traders to file standard information and documents through a single entry point to fulfill all import, export and transit-related regulatory requirements, and shares relevant information with all parties involved including private participants such as banks and insurance companies as well as public agencies such as immigration and vehicle registration authorities.

As of this writing, 71 economies around the world have implemented single-window systems of varying complexity. ${ }^{24}$ In Singapore, the government established the world's first national single window for trade (TradeNet) in 1989, bringing together more than 35 border agencies. ${ }^{25}$ Portugal also implemented an electronic single window for port procedures. The Korea Customs Service estimates that the introduction of a single-window system there brought some $\$ 18$ million in benefits in 2010, a part of the overall economic benefits that year of up to $\$ 3.47$ billion from the agency's trade facilitation efforts. ${ }^{26}$ Indeed, for Korean-based companies such as Samsung and LG, achieving rapid and predictable turnaround times is an important source of their competitiveness.

Use risk-based inspections: Requiring imports and exports to undergo inspections (for tax, security, environmental, border control, and health and safety reasons) is often necessary. Done

\footnotetext{
${ }^{24}$ World Bank Doing Business 2015 Database

${ }^{25}$ Singapore Customs Service. 2007. Annual Report 2006/07. Singapore. http://www.customs.gov.sg/

${ }^{26}$ See Korea Customs Service (2011)
} 
with a heavy hand, however, inspections can be a serious obstacle to efficient and predictable trades.

Over the years, customs administrations around the world have developed systems for establishing risk profiles of products that allow them to apply inspections in proportion to the potential risk. Investing in equipment is another way to help expedite the processing of cargo. Many economies have adopted the use of scanners to limit the need to physically open containers. In some countries, however, the use of scanners has led to further delays because customs agents scan all containers and mandatory scanning fees have added costs for traders. Efficient use of scanners in conjunction with risk-based profiling can strike the right balance in inspection, contributing to the efficiency of the trade process. Risk-based inspections are the norm in OECD high-income economies, but Japan has not adopted the practice. They are also becoming increasingly common elsewhere. Today 134 economies use risk-based inspections.

Improve transparency in trade regulation: Improving transparency in trade regulation by providing easy access to documentation of requirements and tariff schedules can reduce transactions costs for importers and exporters. The average customs clearance cost for exports as measured by Doing Business is $25.3 \%$ lower in those economies where documentation requirements are easily accessible. ${ }^{27}$

Recent literature has emphasized the importance of trade facilitation in explaining trade, access to markets, and increases in per capita income. For example, Clark et al. (2004) found that ports efficiency is an important determinant of shipping costs and in bilateral trade. Also, Djankov et al. (2010) found that each additional day that a product is delayed prior to being shipped reduces trade by more than one percent. Put differently, each day is equivalent to a country distancing itself from its trade partners by about $70 \mathrm{~km}$ on average.

\section{2-9. Enforcing contracts}

Japan currently ranks $16^{\text {th }}$ out of 31 on this index. The Doing Business Enforcing Contracts indicator measures time, cost and procedural complexity to enforce a debt in court between two local businesses. It takes 360 days (or nearly 1 year) from the moment a case is filed until the creditor receives payment and the average cost amounts to $32.2 \%$ of the value of the claim.

Effective commercial dispute resolution has many benefits. Courts can be important for entrepreneurs because they interpret the rules of the market and protect economic rights. Efficient and transparent courts encourage new business relationships because businesses know they can rely on the courts if a new customer fails to pay. Speedy trials are essential for small enterprises, which may lack the resources to stay in business while awaiting the outcome of a long court dispute.

\footnotetext{
${ }^{27}$ World Bank Doing Business 2014 Database
} 
Table A9 shows the details of the information collected by the World Bank to evaluate the ease of enforcing contracts in Tokyo. To improve its rankings on this indicator, Japan can:

- Limit adjournments and make enforcement of judgments more efficient(reform 27)

- Introduce performance measures for judges(reform 28)

- Maintain specialized commercial court(reform 29)

- Expand case management systems and automation(reform 30)

Limit adjournments and make enforcement of judgments more efficient: Judges can limit adjournments. Frequent adjournments slow down contract enforcement in Japan. Adjournments are responsible for 280 days out of the 360 days that it takes to get trial and a judgment, and add another 60 days for enforcement. Time limits should be enforced to reduce long delays in court hearings.

Introduce performance measures for judges: Performance evaluation for judges could be introduced. There are several indicators for the judge performance used in other countries. One of them is the disposition rate, which is calculated by dividing the number of disposed cases (by issuing judgments or settling a case in mediation) by the number of incoming cases.

Maintain specialized commercial court: Austria and Belgium have stand-alone commercial courts. The U.K. and the U.S. have specialized commercial divisions within their courts. Specialized courts have been found to improve efficiency. ${ }^{28}$ Creating specialized commercial courts can result in faster and less costly contract enforcements. One reason for the greater efficiency is that judges become expert in handling commercial disputes. Commercial courts often have less formal procedures. For example, use of oral arguments is permitted even where the general courts require written procedures.

Expand case management systems and automation: Japan could expand the use of case management that currently exists in minimal form and only in limited number of courts. Judicial case management involves monitoring and managing cases in the court docket from the filing of the claim until judgment is rendered. It has proved to be an effective tool for reducing procedural delays at court and for monitoring the performance of judges and court officers. By analyzing court workloads, case management systems can help predict trends and allocate resources strategically. Case management can be particularly successful when courts are computerized and when support functions (such as electronic filing, case tracking, document management, deadline reminders and scheduling of hearings) are all performed automatically. Currently 21 of the 189 economies covered by Doing Business allow electronic filing of the initial complaint in a commercial case. In 12 economies including Korea and Malaysia, the capacity has been introduced only after 2007.

\footnotetext{
${ }^{28}$ See Botero et al (2003).
} 
The cost of enforcing contracts is a key determinant of market performance. For example, Bae and Goyal (2009) showed that banks respond to poor enforceability of contracts by reducing loan amounts, shortening loan maturities, and increasing loan spreads. Also, supported by panel data on Italian provinces and by cross-country evidence, Jappelli et al. (2005) showed that improvements in judicial efficiency reduce credit rationing and increase lending.

\section{2-10. Resolving insolvency}

The Doing Business resolving insolvency indicator identifies the main procedural and administrative bottlenecks in the bankruptcy process. Economies with good bankruptcy procedures can maximize the total value of recovered debt (to be divided among the debtor, the main creditors and possibly the shareholders) with the least cost. Economies with inefficient

insolvency procedures have low recovery rates. ${ }^{29}$ An efficient bankruptcy procedure helps keep economically viable firms in business and encourages creation of new firms, thereby promoting healthy competition in the economy.

Table A10 shows the details of the information collected by the World Bank to evaluate the strengths and weaknesses in existing insolvency regulations in Tokyo. Japan already ranks second in the world on this indicator. To improve its ranking on the ease of resolving insolvency, Japan can:

\section{- $\quad$ Promote specialized courts (reform 31)}

Promote specialized courts: Promoting specialized courts is among the most efficient ways to ensure that insolvency cases receive attention more quickly. It also improves the quality of the judicial system, because it allows judges to specialize in hearing insolvency cases and thus better equips them to make informed decisions. Japan could reduce the length of proceedings to shorter than 0.6 years by creating courts specialized in bankruptcy cases.

\section{What would it take for Japan to be in Top Three?}

Overall, we have identified 31 reforms that Japan can carry out to reduce the cost of doing business. In this section, we classify each reform according to two dimensions. One is whether the reform requires legal changes or not. The other is the extent of political resistance the reform is likely to face.

Identifying whether a reform requires legal changes is straightforward. Predicting the extent of political resistance is not. We asked political scientists who specialize in the Japanese politics to judge whether each reform would face low, somewhat low, somewhat high, or high political resistance. Detailed description of the expert survey is in Appendix 2. We use the

${ }^{29}$ See Crimizi et al (2012) 
average response to classify 31 reforms into three groups: low political resistance (average response between "low" and "somewhat low"), medium political resistance (average response between "somewhat low" and "somewhat high"), and high political resistance (average response between "somewhat high" and "high").

Using both dimensions of classification, we group the reforms into six groups as in Figure 1. For each of the 31 reforms, Table 2 shows whether the reform requires legal changes and the degree of political resistance that the reform is likely to face according to the expert survey. The table also shows the numerical average for the expert survey responses and how much Japan's ranking improves by implementing just that reform. Table 3 summarizes how all the reforms are classified into the six groups in Figure 1.

Of the 31 reforms, we find 6 reforms to be just administrative changes and likely to face low political resistance (Group I). For example, allowing electronic submission and processing of export and import documents would entail only an administrative change in the process. Similarly, reducing the time to register property by introducing fast-track procedures, introducing fast-track procedures and combining certain procedures within the property transfer process at the Legal Affairs Bureau do not require legal changes. Moreover, political resistance for these reforms is expected to be low.

Certain administrative reforms are expected to face medium level of political resistance (Group II). We find 8 of the 31 reforms fall into this category. Reducing the number of procedures to get a construction permit requires a collaborative effort from more than one government agency. These agencies would lose some of their powers in the consolidation process and hence would oppose the reform. Similarly, challenges may arise from limiting adjournments and making enforcement of judgments more efficient, introducing performance measures for judges, maintaining specialized commercial court, and expanding case management systems and automation. These reforms are administrative but are likely to face medium political resistance.

Only one reform is administrative and expected to face high political resistance (Group III). This reform is about introducing performance measures for judges.

There are 16 reforms that require legal changes. Four of these (elimination of the requirement for a company seal, cutting business registration fees, reduction of the number of tax payments, and the creation of a unified legal framework for secured transactions) are expected to face low political resistance (Group IV). On the contrary, for example, reduction of the number of tax payments is actually likely to be popular.

Among the remaining 12 reforms that require legal changes, 9 are expected to face medium political difficulty (Group V). These reforms include promoting specialized courts, reducing corporate profit tax rates, and creating a collateral registry in which all functional equivalents can be registered. We expect the oppositions would come from Ministry of Justice, 
Ministry of Finance, and many corporations. Similarly, establishing a public credit registry for corporations require legal changes and probably will face oppositions from corporation that would lose some privacy.

Only three reforms that need legal changes are expected to face high political resistance (Group VI). These are increasing directors' liability, improving shareholder rights, and enhancing required disclosure.

Table 3 shows that most of the reforms to improve Japan's position in the World Bank's Doing Business Ranking are expected to encounter medium level of political resistance at most. Moreover, about half of these reforms (14 to be exact) with low or medium political resistance do not require legal changes. This is good news for the Japanese government. These reforms would be relatively easy to implement.

Implementing just the reforms in Groups I and II would improve Japan's ranking to \#13 if all the other countries that are ranked higher than Japan currently do not do anything to improve their conditions for doing business. Japan would leapfrog Canada, Estonia, Switzerland, Austria, Portugal, and Netherlands, but would still be ranked lower than New Zealand, the U.S., Denmark, Korea, Norway, United Kingdom, Australia, and Finland. Although not enough to make Japan one of the top three countries, just following through the easy reforms makes a significant difference.

If Japan implements the reforms that require legal changes but are expected to face low political resistance (Group IV) in addition to the in Groups I and II, Japan's ranking jumps to \#6, again if all the other countries do not improve their environments for doing business. Japan would move ahead of Germany, Canada, and Estonia though still looking up New Zealand, the U.S., and Denmark.

When the reforms in Group V, which require legal changes and are expected to face medium political resistance, are implemented, Japan will move to \# 3. Thus, Japan would achieve the KPI of being ranked among top three without implementing politically contentious reforms, under the assumption that the other countries stand still. The assumption that other countries will not do any reforms will certainly turn out to be false. Thus, Japan will probably need to implement some reforms with high political resistance (Groups III and VI) as well, to make sure to be among the top three countries in the ease of doing business ranking. By implementing all the reforms in Groups I-VI, Japan would be ranked \#1 if other countries stand still and increase its chance to be in top 3 even if other countries also reform. 


\section{Concluding remarks}

Improving the environment for business is an important part of the growth strategy (Third Arrow) of Abenomics. As the KPI (Key Performance Indicator) for this effort, the Abe Administration aims to improve Japan's rank in the World Bank Doing Business Ranking from \#15 (in 2013 Report) among high-income OECD countries to one of the top three. Setting a clear target makes sense because the experience of business regulatory reforms elsewhere shows measuring and monitoring the progress of reform is important. For instance, Saudi Arabia used the doing business indicators as part of a scheme to measure its reform progress. In 2005, it set up a 5 -year investment climate reform program and aimed to be among the top 25 in the doing business ranking by $2008 .{ }^{30}$ The reform program was successful and Saudi Arabia was ranked $11^{\text {th }}$ in the World Bank Doing Business 2011 report.

Although the goal may be clear, it is not yet obvious how the Japanese government will try to improve its Ease of Doing Business ranking. This paper clarifies what it takes for Japan to be among top three countries in terms of ease of doing business. By looking at details of the latest World Bank Doing Business ranking, we identify various reforms that Japan could implement to improve the ranking. Then, we classify the potential reforms into six groups depending on whether the reform requires legal changes and the extent of political resistance that the reform is likely to face.

By just doing the reforms that do not require legal changes and are not likely to face strong political opposition, Japan can improve the ranking from the current $19^{\text {th }}$ among highincome OECD countries to \#13, if other countries do not improve their business environments. To be in top 3 is a little bit more difficult, but even that can be achieved without politically difficult reforms. If Japan implements all the reforms except for those which are likely to face high political resistance and if the other countries do not reduce the cost of doing business, it will be ranked \#3. Since the assumption that the other countries do not reform while Japan does is unrealistic, Japan will also need to carry out some politically unpopular reforms in Groups III and VI in order to achieve the KPI becoming one of the top three countries among high-income OECD countries in terms of ease of doing business.

Improving the ranking alone, however, would not guarantee increased business creation in Japan. This fact is because the Doing Business ranking does not look at all the aspects of cost of doing business. For example, to measure the difficulty of dealing with licenses, Doing Business indicators examine the burden of obtaining a permit to build a warehouse. However, firms must deal with licenses in many other areas as well. These licenses include medical devices and drugs, radio stations, mines, bars, banks, insurance companies, airlines, and taxis depending on their business. The cost of doing business in those areas is not covered by the report's indicators. If Japan wants to reduce the cost of doing business generally, the government has to

\footnotetext{
${ }^{30}$ See Belayachi and Haidar (2008)
} 
look at licensing procedures in these other areas, too. International benchmarks may be useful for getting an idea of achievable performance in a particular area, but the key is to improve in all the areas that matter, whether or not they are covered by existing global indicators. ${ }^{31}$

Finally, improving the business environment is just one of the many economic reform areas proposed in Abenomics. Achieving the KPI for this reform area alone would not be sufficient to restore the growth to Japan. Also, there is a social cost for implementing flexibilityenhancing structural reforms that need to be addressed. ${ }^{32}$ Thus, it will be important to have clear KPIs for other growth enhancing reform areas, too, and to achieve those. A problem of Abenomics is that it is not clear on how to achieve the KPIs in many reform areas even when they have clear KPIs. This problem still exists in the 2015 revision of the growth strategy. This paper shows a way to formulate a clear reform plan to achieve the KPI for improving the business environment in Japan. ${ }^{33}$ Similar exercises would be useful in other reform areas as well.

\footnotetext{
${ }^{31}$ Hausmann (2013) argues that countries should not focus too much on improving their rankings. Instead, he argues, the countries should use the information as a catalyst for growth policy debates.

${ }^{32}$ For example, see Boeri et al (2015) which highlights costs of labour market structural reforms

${ }^{33}$ Other countries (i.e. India and Russia) have similar KPIs too (see Besley (2015))
} 


\section{References:}

Alesina, A., Ardagna, S., Nicoletti, G., and Schiantarelli, F., (2005). "Regulation and Investment," Journal of the European Economic Association 3(4): 791-825.

Audretsch, D., Keilbach, M., and Lehmann, E., (2006). Entrepreneurship and Economic Growth, New York: Oxford University Press.

Amin, M., and Haidar, J.I., (2012). "The Cost of Registering Property: Does Legal Origin matter?" Empirical Economics 42(3): 1035-1050.

Amin, M., and Haidar, J.I., (2014). "Trade Facilitation and Country Size," Empirical Economics 47(4): 1441-1466.

Bae, K. and Goyal, V., (2009). "Creditor Rights, Enforcement, and Bank Loans," The Journal of Finance 64(2): 823-860.

Belayachi, K. and Haidar, J.I., (2008). "Competitiveness from Innovation, not Inheritance," In World Bank, Celebrating Reform 2008. Washington, DC: World Bank Group and U.S. Agency for International Development.

Besley, T., and Burgess, R., (2004). "Can Labor Regulation Hinder Economic Performance? Evidence from India," Quarterly Journal of Economics 119(1): 91-134.

Besley, T., (2015). "Law, Regulation, and the Business Climate: The Nature and Influence of the World Bank Doing Business Project," Journal of Economic Perspectives 29(3): 99-120.

Blanchard, O. and Portugal, P., (1998). "What Hides Behind an Unemployment Rate: Comparing Portuguese and U.S. Unemployment", NBER Working Papers 6636, National Bureau of Economic Research.

Boeri, T., Cahuc, P., and Zylberberg, A., (2015). "The Cost of Flexibility-Enhancing Structural Reforms," Bocconi University, Mimeo

Botero, J., La Porta, R., López-de-Silanes, F., Shleifer, A., and Volokh, A., (2003). "Judicial Reform," World Bank Research Observer 18(1): 67-88.

Branstetter, L., Lima, F., Lowell, J., and Venancio, A., (2014). "Do Entry Regulations Deter Entrepreneurship and Job Creation? Evidence from Recent Reforms in Portugal," Economic Journal 124(577): 805-832.

Bruhn, M., (2011). "License to Sell: The Effects of Business Registration Reform on Entrepreneurial Activity in Mexico," Review of Economics and Statistics 93(1): 382-386.

Buiter, W. and Rahbari, E., (2013). "What to Expect from Abenomics," Citi GPS: Global Perspectives \& Solutions. 
Ciccone, A. and Papaioannou, E., (2007). "Red Tape and Delayed Entry," Journal of the European Economic Association 5(2): 444-58.

Cirmizi, E., Klapper, L., and Uttamchandani, M. (2012). "The Challenges of Bankruptcy Reform," World Bank Research Observer 27(2): 185-203.

Clark, X., Dollar, D., and Micco, A., (2004). "Port efficiency, maritime transport costs, and bilateral trade," Journal of Development Economics 75(2): 417-450.

Dabla-Norris, E., Gradstein, M., and Inchauste, G., (2008). "What Causes Firms to Hide Output? The Determinants of Informality," Journal of Development Economics 85(1): 1-27.

Djankov, S., Freund, C., and Pham, C., (2010). "Trading on Time," The Review of Economics and Statistics 92(1): 166-173.

Djankov, S., Mcliesh, C., and Shleifer, A., (2007). "Private Credit in 129 countries," Journal of Financial Economics 84(2): 299-329.

Djankov, S., La Porta, R., López-de-Silanes, F., and Shleifer, A., (2008). "The Law and Economics of Self-Dealing," Journal of Financial Economics 88(3): 430-65.

Djankov, S., (2009). “The Regulation of Entry: a Survey," World Bank Research Observer 24(2): 183-203.

Djankov, S., Ganser, T., McLiesh, C., Ramalho, R., and Shleifer, A., (2010). "The Effect of Corporate Taxes on Investment and Entrepreneurship," American Economic Journal: Macroeconomics 2(3): 31-64.

Doblas-Madrid, A. and Minetti, R., (2013). "Sharing Information in the Credit Market: ContractLevel Evidence from US Firms," Journal of Financial Economics 109(1): 198-223.

Haidar, J.I., (2007). "How Efficiently is Capital Created? Evidence from Property Registration Reform in Egypt", World Bank, Washington, DC.

Haidar, J.I., (2008). "Egypt: How to Raise Revenues by Lowering Fees." In World Bank, Celebrating Reform 2008. Washington, DC: World Bank Group and U.S. Agency for International Development.

Haidar, J.I., (2009). "Protecting Investors and Economic Growth,” Economics Letters 103(1):14.

Haidar, J.I., (2012). "The Impact of Business Regulatory Reforms on Economics Growth", Journal of the Japanese and International Economies 26(3): 285-307.

Haselmann, R., Pistor, K., and Vig, V., (2010). "How Law Affects Lending," Review of Financial Studies 23(2): 549-580. 
Hausman, J. and Wieland, J., (2014). "Abenomics: Preliminary Analysis and Outlook," Brookings Papers on Economic Activity, Spring (2014):1-63.

Hausmann, R. (2013). “What to Do with Doing Business?" Project Syndicate

Holmes, T., (1998). "The Effect of State Policies on the Location of Manufacturing: Evidence from State Borders," Journal of Political Economy 106(4): 667-705.

Hoshi, Takeo (2014). “Can Abenomics Restore Japan's Growth?” Macro Economy Proceedings, Nomura Foundation, January.

Hoshi, T. and Kashyap, A. (2012).“Policy options for Japan's revival,” Columbia University Center on Japanese Economy and Business Working Paper \# 308.

Houston, J., Lin, C., Lin, P., and Ma, Y., (2010). "Creditor Rights, Information Sharing, and Bank Risk Taking,” Journal of Financial Economics 96(3): 485-512.

Japan's Prime Minister's Office (2013). “Japan Revitalization Strategy Short to Mid-Term Progress Schedule," http://www.kantei.go.jp/jp/singi/keizaisaisei/pdf/koutei en.pdf

Jappelli, T., Pagano, M., and Bianco, M., (2005). "Courts and Banks: Effects of Judicial Enforcement on Credit Markets," Journal of Money, Credit and Banking 37(2): 223-44.

Klapper, L. and Love, I., (2010). "The impact of business environment reforms on new firm registration," Policy Research Working Paper Series, 5493, The World Bank.

Klapper, L., Lewin, A., and Delgado, J., (2009). "The Impact of the Business Environment on the Business Creation Process," Policy Research Working Paper 4937, World Bank, Washington, DC.

Klapper, L., Laeven, L., and Rajan, R., (2006). "Entry Regulation as a Barrier to Entrepreneurship," Journal of Financial Economics 82 (3): 591-629.

Klapper, L., Amit, R., and Guillen, M., (2010). "Entrepreneurship and Firm Formation across Countries," In International Differences in Entrepreneurship, ed. Joshua Lerner and Antoinette Shoar. Chicago: University of Chicago Press.

Korea Customs Service (2011). The Embodiment of Business-Friendly Environment by KCS Challenges. Seoul.

KPMG. (2009). Competitive Alternatives: KPMG's Guide to International Business Location

Lee, Y. and Gordon R., (2005). "Tax Structure and Economic Growth," Journal of Public Economics 89 (5-6): 1027-1043.

Lawless, M., (2013). "Do Complicated Tax Systems Prevent Foreign Direct Investment?" Economica 80(317): 1-22. 
Moullier, Thomas, (2009). "Reforming Building Permits: Why Is It Important and What Can IFC Really Do?” International Finance Corporation, Washington, DC.

Vig, V., (2013). "Access to Collateral and Corporate Debt Structure: Evidence from a Natural Experiment," Journal of Finance 68(3): 881-928.

World Bank Group, (2013). "Good Practices for Construction Regulation and Enforcement Reform: Guidelines for Reformers," Investment Climate, Washington, DC.

World Bank, (2014).Doing Business 2014: Understanding Regulations for Small and Medium Size Enterprises Washington, DC.

World Bank Doing Business Database. 
Table 1: Japan's performance and top 5 OECD economies in terms of ease of doing business

\begin{tabular}{|c|c|c|c|}
\hline & \multicolumn{2}{|c|}{ Japan ranking in the } & \multirow{2}{*}{$\begin{array}{l}\text { Ranking of the top } 5 \text { countries in } \\
\text { OECD (from first to fifth) }\end{array}$} \\
\hline & World & OECD & \\
\hline Starting a Business & 83 & 27 & $\begin{array}{l}\text { New Zealand, Canada, Australia, } \\
\text { Portugal, Belgium } \\
\text { Denmark, Germany, Korea, New }\end{array}$ \\
\hline Dealing with Construction Permits & 83 & 19 & $\begin{array}{l}\text { Zealand, United Kingdom } \\
\text { Korea, Germany, Switzerland, }\end{array}$ \\
\hline Getting Electricity & 28 & 9 & $\begin{array}{l}\text { Sweden, Iceland } \\
\text { New Zealand, Norway, Denmark, }\end{array}$ \\
\hline Registering Property & 73 & 23 & $\begin{array}{l}\text { Slovak Republic, Estonia } \\
\text { New Zealand, United States, } \\
\text { Australia, Canada, United }\end{array}$ \\
\hline Getting Credit & 71 & 22 & $\begin{array}{l}\text { Kingdom } \\
\text { New Zealand, United Kingdom, }\end{array}$ \\
\hline Protecting Minority Investors & 35 & 17 & $\begin{array}{l}\text { Ireland, Canada, Israel } \\
\text { Ireland, Canada, Denmark, }\end{array}$ \\
\hline Paying Taxes & 122 & 30 & $\begin{array}{l}\text { Norway, United Kingdom } \\
\text { Korea, Sweden, Ireland, Estonia, }\end{array}$ \\
\hline Trading Across Borders & 20 & 14 & $\begin{array}{l}\text { Denmark } \\
\text { Luxembourg, Iceland, Korea, }\end{array}$ \\
\hline Enforcing Contracts & 26 & 16 & $\begin{array}{l}\text { Austria, Norway } \\
\text { Finland, Japan, Germany, United }\end{array}$ \\
\hline Resolving Insolvency & 2 & 2 & $\begin{array}{l}\text { States, Korea } \\
\text { New Zealand, Denmark, Korea, }\end{array}$ \\
\hline Ease of Doing Business & 29 & 19 & Norway, United States, \\
\hline
\end{tabular}

Note: The source of this information is the World Bank 2015 Doing Business Database. 
Table 2: Expected impact and political resistance of recommended reforms

\begin{tabular}{|c|c|c|c|c|}
\hline Reform name & Reform type & Impact & $\begin{array}{c}\text { Expected } \\
\text { political } \\
\text { resistance }\end{array}$ & $\begin{array}{c}\text { Survey } \\
\text { result }\end{array}$ \\
\hline \multicolumn{5}{|l|}{ Starting a business } \\
\hline $\begin{array}{l}\text { Eliminate the requirement for a company seal } \\
\text { (reform 1) }\end{array}$ & Legal & $\begin{array}{l}\text { Cut } 4 \text { days, } 2 \text { procedures, and cost by } \\
0.53 \% \text { of income per capita. } \\
\text { Improve the rank on the ease of starting a } \\
\text { business by } 11 \text { spots and the overall rank } \\
\text { by } 1 \text { spot }\end{array}$ & Low & 1.4 \\
\hline $\begin{array}{l}\text { Make business registration administrative rather } \\
\text { than judicial(reform 2) }\end{array}$ & Administrative & $\begin{array}{l}\text { Cut } 2 \text { days } \\
\text { Improve rank on the ease of starting a } \\
\text { business by } 10 \text { spots and leave the overall } \\
\text { rank unchanged }\end{array}$ & Low & 1.4 \\
\hline $\begin{array}{l}\text { Create one-stop shop for business registration } \\
\text { (reform 3) }\end{array}$ & Administrative & $\begin{array}{l}\text { Cut } 7 \text { procedures and 10days } \\
\text { Improve the rank on the ease of starting a } \\
\text { business by } 22 \text { spots and the overall rank } \\
\text { by } 1 \text { spot }\end{array}$ & Low & 1.8 \\
\hline Cut registration fees (reform 4) & Legal & $\begin{array}{l}\text { Cut cost by } 6.8 \% \text { of income per capita } \\
\text { Improve the rank on the ease of starting a } \\
\text { business by } 1 \text { spot and leave the overall } \\
\text { rank unchanged }\end{array}$ & Low & 1.9 \\
\hline \multicolumn{5}{|c|}{ Implementing reforms 14 would improve the rank on the ease of starting a business by 22 spots and the overall rank by 1 spot } \\
\hline \multicolumn{5}{|c|}{ Dealing with construction permits } \\
\hline $\begin{array}{l}\text { Reduce number of procedures to get a construction } \\
\text { permit (reform 5) }\end{array}$ & Administrative & $\begin{array}{l}\text { Cut } 7 \text { procedures } \\
\text { Improve the rank on the ease of dealing } \\
\text { with construction permits by } 8 \text { spots and } \\
\text { the overall rank by } 1 \text { spot }\end{array}$ & Medium & 2.0 \\
\hline $\begin{array}{l}\text { Reduce the time to issue a construction permit } \\
\text { (reform 6) }\end{array}$ & Administrative & $\begin{array}{l}\text { Cut } 130 \text { days } \\
\text { Improve the rank on the ease of dealing } \\
\text { with construction permits by } 8 \text { spots and } \\
\text { the overall rank by } 1 \text { spot }\end{array}$ & Medium & 2.1 \\
\hline
\end{tabular}




\begin{tabular}{|c|c|c|c|c|}
\hline \multicolumn{4}{|c|}{$\begin{array}{l}\text { Implementing reforms 5-6 would improve the rank on the ease of dealing with construction permits by } 17 \text { spots and the overall rank } \\
\text { by } 2 \text { spots }\end{array}$} & \multirow[b]{3}{*}{2.1} \\
\hline \multicolumn{4}{|c|}{ Getting electricity } & \\
\hline $\begin{array}{l}\text { Reduce the number of days it takes to get electricity } \\
\text { by } 80 \text { days by improving process efficiency (reform } \\
\text { 7) }\end{array}$ & Administrative & $\begin{array}{l}\text { Cut } 80 \text { days } \\
\text { Improve the rank on the ease of getting } \\
\text { electricity by } 4 \text { spots and the overall rank } \\
\text { by } 1 \text { spot }\end{array}$ & Medium & \\
\hline \multicolumn{5}{|l|}{ Registering property } \\
\hline $\begin{array}{l}\text { Reduce the time to register property by introducing } \\
\text { fast-track procedures (reform 8) }\end{array}$ & Administrative & $\begin{array}{l}\text { Cut } 8 \text { days } \\
\text { The rank on the ease of registering } \\
\text { property and the overall rank will not } \\
\text { change }\end{array}$ & Low & 1.7 \\
\hline $\begin{array}{l}\text { Combine and eliminate some procedures for } \\
\text { registering property (reform 9) }\end{array}$ & Administrative & $\begin{array}{l}\text { Cut } 2 \text { procedures (days will not change as } \\
\text { those procedures are simultaneous) } \\
\text { Improve the rank on the ease of } \\
\text { registering property by } 7 \text { spots and the } \\
\text { overall rank by } 1 \text { spot }\end{array}$ & Medium & 2.0 \\
\hline Lower property registration fees (reform 10) & Legal & $\begin{array}{l}\text { Reduce cost to } 0.1 \% \text { of property value } \\
\text { Improve the rank on the ease of } \\
\text { registering property by } 11 \text { spots and the } \\
\text { overall rank by } 1 \text { spot }\end{array}$ & Medium & 2.7 \\
\hline \multicolumn{5}{|c|}{ Implementing reforms $8-10$ would improve the rank on the ease of registering property by 15 spots and the overall rank by 2 spots } \\
\hline \multicolumn{5}{|c|}{\begin{tabular}{|l|l|l|l|} 
Getting credit & & & \\
\end{tabular}} \\
\hline $\begin{array}{l}\text { Create a unified legal framework for secured } \\
\text { transactions including creation, publicity and } \\
\text { enforcement of security interests in movable assets } \\
\text { (reform 11) }\end{array}$ & Legal & $\begin{array}{l}\text { Increase the strength of legal rights index } \\
\text { by } 3 \text { points } \\
\text { Improve the rank on the ease of getting } \\
\text { credit by } 7 \text { spots and the overall rank by } 1 \\
\text { spot }\end{array}$ & Low & 1.9 \\
\hline $\begin{array}{l}\text { Create a collateral registry in which all functional } \\
\text { equivalents can be registered (reform 12) }\end{array}$ & Legal & $\begin{array}{l}\text { Increase the strength of legal rights index } \\
\text { by } 3 \text { points } \\
\text { Improve the rank on the ease of getting } \\
\text { credit by } 7 \text { spots and the overall rank by } 1 \\
\text { spot }\end{array}$ & Medium & 2.3 \\
\hline
\end{tabular}




\begin{tabular}{|c|c|c|c|c|}
\hline Reform bankruptcy law (reform 13) & Legal & $\begin{array}{l}\text { Increase the strength of legal rights index } \\
\text { by } 2 \text { points } \\
\text {. Improve the rank on the ease of getting } \\
\text { credit by } 7 \text { spots and the overall rank by } 1 \\
\text { spot }\end{array}$ & Medium & 2.6 \\
\hline $\begin{array}{l}\text { Establish a public credit registry for corporations } \\
\text { (reform 14) }\end{array}$ & Legal & $\begin{array}{l}\text { Increase the depth of credit information } \\
\text { index by } 1 \text { point } \\
\text { Improve the rank on the ease of getting } \\
\text { credit by } 7 \text { spots and the overall rank by } 1 \\
\text { spot }\end{array}$ & Medium & 2.5 \\
\hline \multicolumn{5}{|c|}{ Implementing reforms 11-14 would improve the rank on the ease of getting credit by 17 spots and the overall rank by 3 spots } \\
\hline \multicolumn{5}{|c|}{\begin{tabular}{l|l|l|l} 
Protecting minority investors & & & \\
\end{tabular}} \\
\hline Increase disclosure requirements (reform 15) & Legal & $\begin{array}{l}\text { Increase the extent of disclosure index by } \\
3 \text { points } \\
\text { Improve the rank on the protecting } \\
\text { minority investors by } 8 \text { spots and the } \\
\text { overall rank by } 1 \text { spot }\end{array}$ & Medium & 2.7 \\
\hline Increase directors' liability (reform 16) & Legal & $\begin{array}{l}\text { Increase the extent of director liability } \\
\text { index by } 4 \text { points } \\
\text { Improve the rank on the protecting } \\
\text { minority investors by } 10 \text { spots and the } \\
\text { overall rank by } 1 \text { spot }\end{array}$ & High & 3 \\
\hline $\begin{array}{l}\text { Allow the plaintiff of a shareholder suit to request } \\
\text { categories of documents without identifying specific } \\
\text { ones (reform 17) }\end{array}$ & Legal & $\begin{array}{l}\text { Increase the ease of shareholder suits } \\
\text { index by } 1 \text { point } \\
\text { Improve the rank on the protecting } \\
\text { minority investors by } 7 \text { spots and leave the } \\
\text { overall rank unchanged }\end{array}$ & High & 3 \\
\hline Strengthen governance structure (reform 18) & Legal & $\begin{array}{l}\text { Increase the strength of governance } \\
\text { structure index by } 6 \text { points } \\
\text { Improve the rank on the protecting } \\
\text { minority investors by } 11 \text { spots and the } \\
\text { overall rank by } 1 \text { spot }\end{array}$ & Medium & 2.8 \\
\hline
\end{tabular}




\begin{tabular}{|c|c|c|c|c|}
\hline Enhance corporate transparency (reform 19) & Legal & $\begin{array}{l}\text { Increase the extent of corporate } \\
\text { transparency index by } 3 \text { points } \\
\text { Improve the rank on the protecting } \\
\text { minority investors by } 8 \text { spots and the } \\
\text { overall rank by } 1 \text { spot }\end{array}$ & Medium & 2.1 \\
\hline Improve shareholder rights (reform 20) & Legal & $\begin{array}{l}\text { Increase the extent of shareholder rights } \\
\text { index by } 3 \text { points } \\
\text { Improve the rank on the protecting } \\
\text { minority investors by } 8 \text { spots and the } \\
\text { overall rank by } 1 \text { spot }\end{array}$ & Medium & 2.7 \\
\hline \multicolumn{5}{|c|}{$\begin{array}{l}\text { Implementing reforms } 15-20 \text { would improve the rank on protecting minority investors by } 16 \text { spots (to \#1) and the overall rank by } 2 \\
\text { spots }\end{array}$} \\
\hline \multicolumn{5}{|c|}{\begin{tabular}{l|l|l|} 
Paying taxes & & \\
\end{tabular}} \\
\hline Reduce number of payments (reform 21) & Legal & $\begin{array}{l}\text { Reduce number of payments (to } 4 \text { ) and } \\
\text { hours needed to pay taxes (to } 233 \text { ) } \\
\text { Improve the overall rank byl spots but } \\
\text { leave the rank on the ease of paying taxes } \\
\text { unchanged }\end{array}$ & Low & 1.8 \\
\hline Reduce corporate profit tax rate (reform 22) & Legal & $\begin{array}{l}\text { Reduce profit tax rate to } 31.2 \% \text { from its } \\
\text { current } 51.3 \% \\
\text { Improve the rank on the ease of paying } \\
\text { taxes by } 3 \text { spots and the overall rank by } \\
1 \text { spot }\end{array}$ & Medium & 2.7 \\
\hline \multicolumn{5}{|c|}{ Implementing reforms 21-22 would improve the rank on the ease of paying taxes by 6 spots and the overall rank by 1 spot } \\
\hline \multicolumn{5}{|c|}{ Trading across borders } \\
\hline \multirow{4}{*}{$\begin{array}{l}\text { Allow electronic submission and processing (reform } \\
\text { 23) } \\
\text { Link agencies through an electronic single window } \\
\text { (reform 24) } \\
\text { Use risk-based inspections (reform 25) } \\
\text { Improve transparency in trade regulation (reform } \\
\text { 26) }\end{array}$} & \multirow{4}{*}{ Administrative } & \multirow{4}{*}{$\begin{array}{l}\text { Reduce time, number of documents, and } \\
\text { cost for cross-border trading to } 5 \text { days, } 2 \\
\text { documents, and } 600 \text { USD, respectively } \\
\text { Improve the rank on the ease of trading } \\
\text { across borders by } 13 \text { spots (to \#1) and the } \\
\text { overall rank by } 1 \text { spot }\end{array}$} & Low & 1.3 \\
\hline & & & Low & 1.2 \\
\hline & & & Medium & 2.2 \\
\hline & & & Low & 1.2 \\
\hline
\end{tabular}




\begin{tabular}{|c|c|c|c|c|}
\hline Enforcing contracts & & & & \\
\hline \multirow{3}{*}{$\begin{array}{l}\text { Limit adjournments and make enforcement of } \\
\text { judgments more efficient (reform 27) } \\
\text { Introduce performance measures for judges (reform } \\
28 \text { ) } \\
\text { Maintain specialized commercial court (reform 29) } \\
\text { Expand case management systems and automation } \\
\text { (reform 30) }\end{array}$} & \multirow[t]{3}{*}{ Administrative } & \multirow{3}{*}{$\begin{array}{l}\text { Reduce time to } 150 \text { days } \\
\text { Improve the rank on the ease of enforcing } \\
\text { contracts by } 5 \text { spots and the overall rank by } \\
1 \text { spot }\end{array}$} & \multirow{3}{*}{$\begin{array}{c}\text { Medium } \\
\text { High } \\
\text { Medium } \\
\text { Medium }\end{array}$} & 2.0 \\
\hline & & & & 2.4 \\
\hline & & & & 2.2 \\
\hline \multicolumn{5}{|l|}{ Resolving insolvency } \\
\hline Promote specialized courts (reform 31) & Legal & $\begin{array}{l}\text { Improve the rank on the ease of resolving } \\
\text { insolvency by } 1 \text { spots (to } \# 1 \text { ) but leave the } \\
\text { overall rank unchanged }\end{array}$ & Medium & 2.6 \\
\hline
\end{tabular}

Notes: "Impact" column shows what would happen when that reform alone without any other reforms was implemented. Thus, the impact on ranking is the marginal impact evaluated at the status quo. All rankings in Table 2 refer to OECD ranking (column 3 of Table 1). To capture "expected political resistance", we sought the help of 27 political scientists, who are experts on Japanese politics and institutions, in gauging the extent of political challenges each reform is likely to face. In a survey, for each of the reforms, we asked the experts to judge the extent of political resistance that the reform is likely to face using the following four point scale: (1) The reform is expected to face low political resistance; (2) The reform is expected to face somewhat low political resistance; (3) The reform is expected to face somewhat high political resistance; and (4) The reform is expected to face high political resistance. Then, for each of the reforms, we used the average response value. We came up with three groups of political resistance: low $(1<=$ average score $<2)$, middle $(2<=$ average score $<3)$, high $(3<=$ average score $<=4)$. 
Table 3: Classification of Reforms for Japan

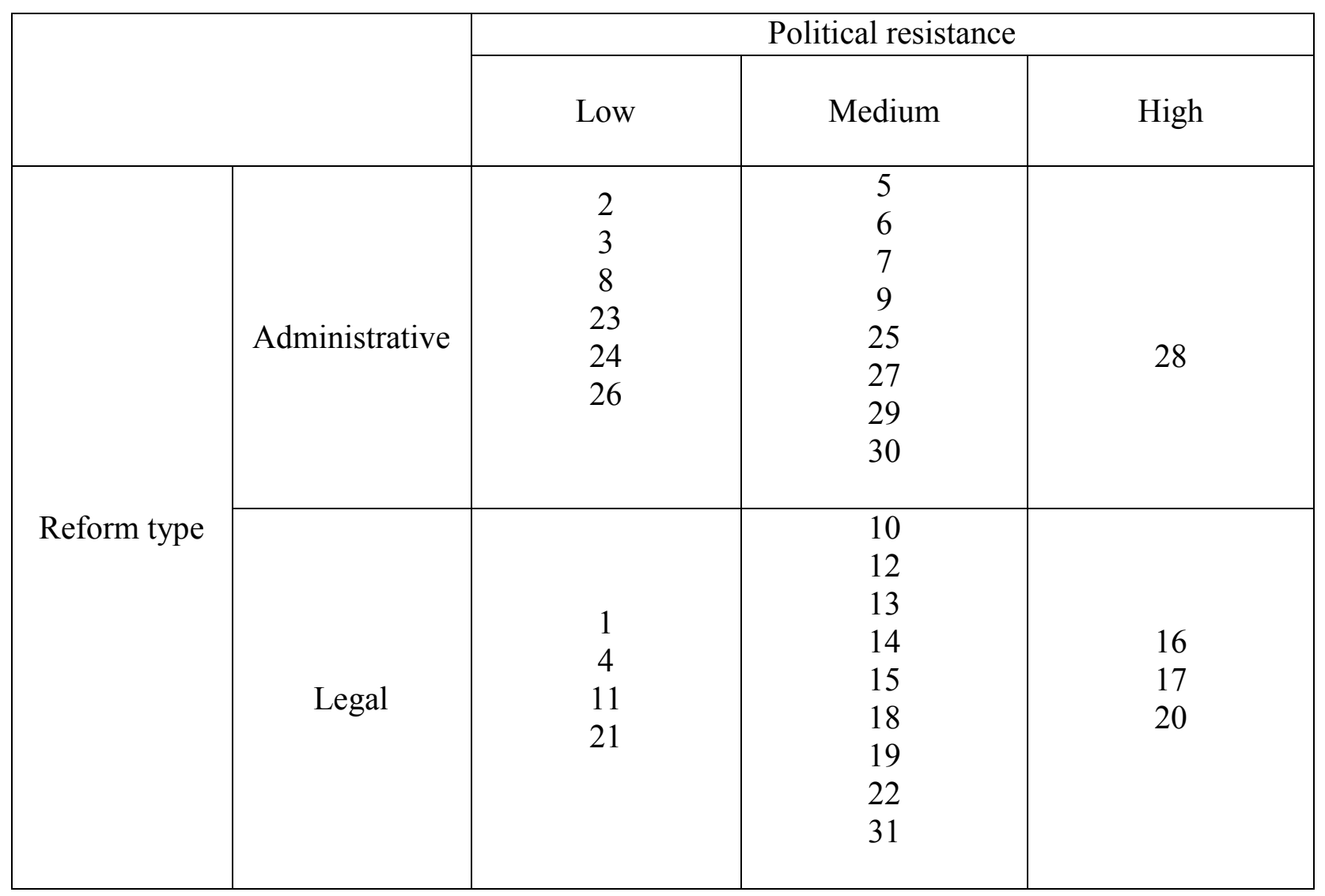


Figure 1. Classification of Reforms

Political Resistance

Low Medium High

\begin{tabular}{cc|c|c|c|}
\cline { 3 - 4 } \multicolumn{1}{c}{ Legal } & Not Necessary & Group I & Group II & Group III \\
\cline { 3 - 5 } Change & Necessary & Group IV & Group V & Group VI \\
\cline { 3 - 5 } & & & & \\
\end{tabular}




\section{Appendix 1. World Bank Evaluation of Ease of Doing Business in Japan for Each of the Ten Areas}

Source: World Bank Doing Business Database, 2015

Table A1. Procedures, time, and costs associated with starting a business in Tokyo

\begin{tabular}{|l|l|l|l|}
\hline No. & Procedure & Time & Costs \\
\hline 1 & $\begin{array}{l}\text { Search the company name and obtain the certificate } \\
\text { of seal registration from the Legal Affairs Bureau }\end{array}$ & 1 day & JPY 450 (each) \\
\hline 2 & Make a company seal & 3 days & $\begin{array}{l}\text { JPY 10,000 - JPY } \\
20,000\end{array}$ \\
\hline 3 & $\begin{array}{l}\text { Register at the Legal Affairs Bureau of the Ministry } \\
\text { of Justice }\end{array}$ & 3 days & $\begin{array}{l}0.7 \% \text { of the capital } \\
\text { amount or JPY } \\
60,000, \text { whichever } \\
\text { is higher }\end{array}$ \\
\hline 4 & $\begin{array}{l}\text { File the notification of company incorporation and } \\
\text { the opening of a payroll office; and Apply for the } \\
\text { approval of blue tax returns at the District Tax } \\
\text { Office }\end{array}$ & 1 day & no charge \\
\hline 5 & $\begin{array}{l}\text { File the notification of commencement of business } \\
\text { at the tax office of the municipal or prefectural } \\
\text { government }\end{array}$ & 1 day & no charge \\
\hline 6 & $\begin{array}{l}\text { File the necessary labor insurance notifications and } \\
\text { employment rules at the Labor Standards Inspection } \\
\text { Office }\end{array}$ & 1 day & no charge \\
\hline 7 & $\begin{array}{l}\text { File the applications for health insurance and public } \\
\text { welfare pension at the Japan Pension Service }\end{array}$ & $\begin{array}{l}\text { Less than one day } \\
\text { (online procedure) }\end{array}$ & no charge \\
\hline 8 & $\begin{array}{l}\text { File the company application for employment } \\
\text { insurance at the Public Employment Security Office }\end{array}$ & $\begin{array}{l}\text { Less than one day } \\
\text { (online procedure) }\end{array}$ & no charge \\
\hline
\end{tabular}


Table A2. Procedures, time, and costs associated with dealing with construction permits in Tokyo

\begin{tabular}{|l|l|l|l|}
\hline No. & Procedure & Time & Costs \\
\hline 1 & Hold initial consultation with local authority & 24 days & no charge \\
\hline$* 2$ & Obtain consent of neighborhood & 30 days & no charge \\
\hline 3 & Obtain building permit from Japan Building Center & 70 days & JPY 225,000 \\
\hline$* 4$ & $\begin{array}{l}\text { Request and obtain workmen's compensation } \\
\text { insurance proof from Labor Control Office }\end{array}$ & 60 days & no charge \\
\hline 5 & $\begin{array}{l}\text { Purchase and post statutory construction notice sign } \\
\text { board }\end{array}$ & 1 day & JPY 50,000 \\
\hline 6 & $\begin{array}{l}\text { Submit construction method plan to local authority } \\
\text { and obtain approval }\end{array}$ & 7 days & no charge \\
\hline 7 & $\begin{array}{l}\text { Submit project safety and health and resources } \\
\text { recycling plan to local authority and obtain approval }\end{array}$ & 7 days & no charge \\
\hline 8 & $\begin{array}{l}\text { Receive intermediate inspection by Japan Building } \\
\text { Center and obtain permit }\end{array}$ & 24 days & JPY 211,000 \\
\hline 9 & $\begin{array}{l}\text { Request and receive connection to water and } \\
\text { sewage services }\end{array}$ & 21 days & no charge \\
\hline 10 & $\begin{array}{l}\text { Request and receive final inspection from Japan } \\
\text { Building Center }\end{array}$ & 7 days & JPY 220,000 \\
\hline 11 & Obtain completion certificate & 18 days & no charge \\
\hline 12 & $\begin{array}{l}\text { Register the building with the Land and Building } \\
\text { Registry }\end{array}$ & 12 days & JPY 389,275 \\
\hline
\end{tabular}

Table A3. Procedures, time, and costs associated with obtaining access to electricity in Tokyo

\begin{tabular}{|l|l|l|l|}
\hline No. & Procedure & Time & Costs \\
\hline 1 & $\begin{array}{l}\text { Obtain discussion with TEPCO on the actual } \\
\text { construction date and effective date of contract }\end{array}$ & 1 day & JPY 0 \\
\hline 2 & $\begin{array}{l}\text { Submit application at TEPCO and await start of } \\
\text { external connection works }\end{array}$ & 93 days & JPY 0 \\
\hline 3 & $\begin{array}{l}\text { TEPCO carries out connection works and } \\
\text { installation of meter }\end{array}$ & 11 days & JPY 0 \\
\hline
\end{tabular}


Table A4. Procedures, time, and costs associated with registering property in Tokyo

\begin{tabular}{|c|c|c|c|}
\hline No. & Procedure & Time & Costs \\
\hline 1 & $\begin{array}{l}\text { The seller obtains a certificate of evaluation for } \\
\text { fixed asset tax of the real property at a local tax } \\
\text { office }\end{array}$ & $\begin{array}{l}\text { day } \\
\text { (simultaneous with } \\
\text { Procedures 2,3, } \\
\text { and 4) }\end{array}$ & $\begin{array}{l}\text { JPY } 400 \text { for land }+ \\
\text { JPY } 400 \text { for } \\
\text { building }\end{array}$ \\
\hline$* 2$ & Obtain stamps for stamp duty at a post office & $\begin{array}{l}1 \text { day } \\
\text { (simultaneous with } \\
\text { Procedures 1,2, } \\
\text { and 4) }\end{array}$ & JPY 80,000 \\
\hline *3 3 & Obtain a corporate registry certificate & $\begin{array}{l}\text { Less than a day } \\
\text { (online procedure } \\
\text { simultaneous with } \\
\text { Procedures 1, 2, } \\
\text { and 4) }\end{array}$ & $\begin{array}{l}\text { JPY } 600 \text { each copy } \\
\text { or JPY } 480 \text { each } \\
\text { copy online }\end{array}$ \\
\hline$* 4$ & $\begin{array}{l}\text { Obtain a certificate of Seller's seal impression } \\
\text { (inkanshomei) }\end{array}$ & $\begin{array}{l}\text { Less than a day } \\
\text { (online procedure } \\
\text { simultaneous with } \\
\text { Procedures 1, 2, } \\
\text { and 3) }\end{array}$ & $\begin{array}{l}\text { JPY } 450 \text { each copy } \\
\text { JPY } 390 \text { online }\end{array}$ \\
\hline 5 & File an application at the Legal Affairs Bureau & 7-10 days & $\begin{array}{l}2 \% \text { of building } \\
\text { value }+1.5 \% \text { of } \\
\text { land value } \\
\text { evaluated for fixed } \\
\text { asset tax } \\
\text { (registration and } \\
\text { license tax) }\end{array}$ \\
\hline 6 & Payment of the real property acquisition tax & 1 day & $\begin{array}{l}4 \% \text { of property } \\
\text { price evaluated for } \\
\text { fixed asset tax }\end{array}$ \\
\hline
\end{tabular}


Table A5. The strength of credit reporting systems and the effectiveness of collateral and bankruptcy laws in facilitating lending in Tokyo

\begin{tabular}{|l|l|l|l|}
\hline Depth of credit information index (0-8) & $\begin{array}{l}\text { Private credit } \\
\text { bureau }\end{array}$ & $\begin{array}{l}\text { Public credit } \\
\text { registry }\end{array}$ & Score \\
\hline Are data on both firms and individuals distributed? & No & No & 0 \\
\hline Are both positive and negative credit data distributed? & Yes & No & 1 \\
\hline $\begin{array}{l}\text { Are data from retailers or utility companies - in addition to } \\
\text { data from banks and financial institutions - distributed? }\end{array}$ & Yes & No & 1 \\
\hline $\begin{array}{l}\text { Are at least 2 years of historical data distributed? (Credit } \\
\text { bureaus and registries that distribute more than 10 years of } \\
\text { negative data or erase data on defaults as soon as they are } \\
\text { repaid obtain a score of 0 for this component.) }\end{array}$ & Yes & No & 1 \\
\hline $\begin{array}{l}\text { Are data on loan amounts below 1\% of income per capita } \\
\text { distributed? }\end{array}$ & Yes & No & 1 \\
\hline $\begin{array}{l}\text { By law, do borrowers have the right to access their data in } \\
\text { the credit bureau or credit registry? }\end{array}$ & Yes & No & 1 \\
\hline $\begin{array}{l}\text { Can banks and financial institutions access borrowers' } \\
\text { credit information online (for example, through an online } \\
\text { platform, a system-to-system connection or both)? }\end{array}$ & Yes & No & 1 \\
\hline $\begin{array}{l}\text { Are bureau or registry credit scores offered as a value- } \\
\text { added service to help banks and financial institutions asses } \\
\text { the creditworthiness of borrowers? }\end{array}$ & No & No & 0 \\
\hline $\begin{array}{c}\text { Score ("yes" to either public bureau or private registry) } \\
\text { no }\end{array}$ & & 6 \\
\hline
\end{tabular}




\section{Table A5 (continued)}

\begin{tabular}{|c|c|}
\hline Strength of legal rights index $(0-12)$ & \\
\hline $\begin{array}{l}\text { Does an integrated or unified legal framework for secured transactions that } \\
\text { extends to the creation, publicity and enforcement of functional equivalents to } \\
\text { security interests in movable assets exist in the economy? }\end{array}$ & No \\
\hline $\begin{array}{l}\text { Does the law allow businesses to grant a non-possessory security right in a } \\
\text { single category of movable assets, without requiring a specific description of } \\
\text { collateral? }\end{array}$ & Yes \\
\hline $\begin{array}{l}\text { Does the law allow businesses to grant a non-possessory security right in } \\
\text { substantially all of its assets, without requiring a specific description of } \\
\text { collateral? }\end{array}$ & No \\
\hline $\begin{array}{l}\text { May a security right extend to future or after-acquired assets, and may it extend } \\
\text { automatically to the products, proceeds or replacements of the original assets? }\end{array}$ & No \\
\hline $\begin{array}{l}\text { Is a general description of debts and obligations permitted in collateral } \\
\text { agreements; can all types of debts and obligations be secured between parties; } \\
\text { and can the collateral agreement include a maximum amount for which the } \\
\text { assets are encumbered? }\end{array}$ & Yes \\
\hline $\begin{array}{l}\text { Is a collateral registry in operation for both incorporated and non-incorporated } \\
\text { entities, that is unified geographically and by asset type, with an electronic } \\
\text { database indexed by debtor's name? }\end{array}$ & No \\
\hline $\begin{array}{l}\text { Does a notice-based collateral registry exist in which all functional equivalents } \\
\text { can be registered? }\end{array}$ & No \\
\hline $\begin{array}{l}\text { Does a modern collateral registry exist in which registrations, amendments, } \\
\text { cancellations and searches can be performed online by any interested third } \\
\text { party? }\end{array}$ & No \\
\hline $\begin{array}{l}\text { Are secured creditors paid first (i.e. before tax claims and employee claims) } \\
\text { when a debtor defaults outside an insolvency procedure? }\end{array}$ & Yes \\
\hline $\begin{array}{l}\text { Are secured creditors paid first (i.e. before tax claims and employee claims) } \\
\text { when a business is liquidated? }\end{array}$ & No \\
\hline $\begin{array}{l}\text { Are secured creditors subject to an automatic stay on enforcement when a debtor } \\
\text { enters a court-supervised reorganization procedure? Does the law protect } \\
\text { secured creditors' rights by providing clear grounds for relief from the stay } \\
\text { and/or sets a time limit for it? }\end{array}$ & No \\
\hline $\begin{array}{l}\text { Does the law allow parties to agree on out of court enforcement at the time a } \\
\text { security interest is created? Does the law allow the secured creditor to sell the } \\
\text { collateral through public auction and private tender, as well as, for the secured } \\
\text { creditor to keep the asset in satisfaction of the debt? }\end{array}$ & Yes \\
\hline Score (number of "yes" responses) & 4 \\
\hline
\end{tabular}


Table A6. The strength of minority shareholders protections in Tokyo

\begin{tabular}{|c|c|c|}
\hline Indicator & Score & Score Description \\
\hline Extent of disclosure index $(0-10)$ & 7 & \\
\hline $\begin{array}{l}\text { Which corporate body can provide legally sufficient approval for } \\
\text { the Buyer-Seller transaction? }(0-3)\end{array}$ & 2 & $\begin{array}{l}\text { Board of directors } \\
\text { excluding interested } \\
\text { members }\end{array}$ \\
\hline $\begin{array}{l}\text { Is disclosure by the interested director to the board of directors } \\
\text { required? }(0-2)\end{array}$ & 2 & $\begin{array}{l}\text { Full disclosure of all } \\
\text { material facts }\end{array}$ \\
\hline $\begin{array}{l}\text { Is disclosure of the transaction in published periodic filings } \\
\text { (annual reports) required? }(0-2)\end{array}$ & 2 & $\begin{array}{l}\text { Disclosure on the } \\
\text { transaction and on the } \\
\text { conflict of interest }\end{array}$ \\
\hline $\begin{array}{l}\text { Is immediate disclosure of the transaction to the public and/or } \\
\text { shareholders required? }(0-2)\end{array}$ & 1 & $\begin{array}{l}\text { Disclosure on the } \\
\text { transaction only }\end{array}$ \\
\hline $\begin{array}{l}\text { Must an external body review the terms of the transaction before } \\
\text { it takes place? }(0-1)\end{array}$ & 0 & No \\
\hline Extent of director liability index $(0-10)$ & 6 & \\
\hline $\begin{array}{l}\text { Can shareholders sue directly or derivatively for the damage } \\
\text { caused by the Buyer-Seller transaction to the company? }(0-1)\end{array}$ & 1 & Yes \\
\hline $\begin{array}{l}\text { Can shareholders hold the interested director liable for the } \\
\text { damage caused by the transaction to the company? }(0-2)\end{array}$ & 2 & $\begin{array}{l}\text { Liable if unfair or } \\
\text { prejudicial }\end{array}$ \\
\hline $\begin{array}{l}\text { Can shareholders hold members of the approving body liable for } \\
\text { the damage cause by the transaction to the company? }(0-2)\end{array}$ & 2 & $\begin{array}{l}\text { Liable if unfair or } \\
\text { prejudicial }\end{array}$ \\
\hline $\begin{array}{l}\text { Must the interested director pay damages for the harm caused to } \\
\text { the company upon a successful claim by a shareholder plaintiff? } \\
(0-1)\end{array}$ & 1 & Yes \\
\hline $\begin{array}{l}\text { Must the interested director repay profits made from the } \\
\text { transaction upon a successful claim by a shareholder plaintiff? (0- } \\
\text { 1) }\end{array}$ & 0 & No \\
\hline $\begin{array}{l}\text { Can both fines and imprisonment be applied against the interested } \\
\text { director? }(0-1)\end{array}$ & 0 & No \\
\hline $\begin{array}{l}\text { Can a court void the transaction upon a successful claim by a } \\
\text { shareholder plaintiff? }(0-2)\end{array}$ & 0 & $\begin{array}{l}\text { Only in case of fraud or } \\
\text { bad faith }\end{array}$ \\
\hline Ease of shareholder suits index $(0-10)$ & 8 & \\
\hline $\begin{array}{l}\text { Before filing suit, can shareholders owning } 10 \% \text { of the } \\
\text { company's share capital inspect the transaction documents? }(0-1)\end{array}$ & 1 & Yes \\
\hline $\begin{array}{l}\text { Can the plaintiff obtain any documents from the defendant and } \\
\text { witnesses during trial? }(0-3)\end{array}$ & 3 & Any relevant document \\
\hline $\begin{array}{l}\text { Can the plaintiff request categories of documents from the } \\
\text { defendant without identifying specific ones? }(0-1)\end{array}$ & 0 & No \\
\hline $\begin{array}{l}\text { Can the plaintiff directly question the defendant and witnesses } \\
\text { during trial? (0-2) }\end{array}$ & 2 & Yes \\
\hline $\begin{array}{l}\text { Is the level of proof required for civil suits lower than that of } \\
\text { criminal cases? }(0-1)\end{array}$ & 1 & Yes \\
\hline $\begin{array}{l}\text { Can shareholder plaintiffs recover their legal expenses from the } \\
\text { company? }(0-2)\end{array}$ & 1 & Yes if successful \\
\hline
\end{tabular}


Table A6 (Continued)

\begin{tabular}{|c|c|c|}
\hline Indicator & Score & Score Description \\
\hline Extent of shareholder rights index $(0-10.5)$ & 7.5 & \\
\hline $\begin{array}{l}\text { Can shareholders amend company bylaws or statutes with a } \\
\text { simple majority? }\end{array}$ & 0 & No \\
\hline $\begin{array}{l}\text { Can shareholders owning } 10 \% \text { of the company's share capital call } \\
\text { for an extraordinary meeting of shareholders? }\end{array}$ & 1.5 & Yes \\
\hline $\begin{array}{l}\text { Can shareholders remove members of the board of directors } \\
\text { before the end of their terms. }\end{array}$ & 1.5 & Yes \\
\hline $\begin{array}{l}\text { Must a company obtain its shareholders' approval every time it } \\
\text { issues new shares? }\end{array}$ & 1.5 & Yes \\
\hline $\begin{array}{l}\text { Are shareholders automatically granted subscription rights on } \\
\text { new shares? }\end{array}$ & 0 & No \\
\hline $\begin{array}{l}\text { Must shareholders approve the election and dismissal of the } \\
\text { external auditor? }\end{array}$ & 1.5 & Yes \\
\hline $\begin{array}{l}\text { Can shareholders freely trade shares prior to a major corporate } \\
\text { action or meeting of shareholders? }\end{array}$ & 1.5 & Yes \\
\hline Strength of governance structure index $(0-10.5)$ & 4.5 & \\
\hline $\begin{array}{l}\text { Is the CEO barred from also serving as chair of the board of } \\
\text { directors? }\end{array}$ & 0 & No \\
\hline Must the board of directors include independent board members? & 1.5 & Yes \\
\hline Must a company have a separate audit committee? & 0 & No \\
\hline $\begin{array}{l}\text { Must changes to the voting rights of a series or class of shares be } \\
\text { approved only by the holders of the affected shares? }\end{array}$ & 1.5 & Yes \\
\hline $\begin{array}{l}\text { Must a potential acquirer make a tender offer to all shareholders } \\
\text { upon acquiring } 50 \% \text { of a company? }\end{array}$ & 0 & No \\
\hline $\begin{array}{l}\text { Is cross-shareholding between } 2 \text { independent companies limited } \\
\text { to } 10 \% \text { of outstanding shares? }\end{array}$ & 0 & No \\
\hline $\begin{array}{l}\text { Is a subsidiary barred from acquiring shares issued by its parent } \\
\text { company? }\end{array}$ & 1.5 & Yes \\
\hline Extent of corporate transparency index $(0-9)$ & 4.5 & \\
\hline Must ownership stakes representing $10 \%$ be disclosed? & 0 & No \\
\hline $\begin{array}{l}\text { Must information about board members' other directorships as } \\
\text { well as basic information on their primary employment be } \\
\text { disclosed? }\end{array}$ & 1 & $\begin{array}{l}\text { Yes for listed } \\
\text { companies }\end{array}$ \\
\hline Must the compensation of individual managers be disclosed? & 0 & No \\
\hline $\begin{array}{l}\text { Must financial statements contain explanatory notes on } \\
\text { significant accounting policies, trends, risks, uncertainties and } \\
\text { other factors influencing the reporting? }\end{array}$ & 1.5 & Yes \\
\hline $\begin{array}{l}\text { Must annual financial statements be audited by an external } \\
\text { auditor? }\end{array}$ & 1 & $\begin{array}{l}\text { Yes for listed } \\
\text { companies }\end{array}$ \\
\hline Must audit reports be disclosed to the public? & 1 & $\begin{array}{l}\text { Yes for listed } \\
\text { companies }\end{array}$ \\
\hline
\end{tabular}


Table A7. Taxes and mandatory contributions that would be paid by a standard company in Tokyo

\begin{tabular}{|c|c|c|c|c|c|}
\hline Tax (contribution) & $\begin{array}{l}\text { Payments } \\
\text { (number) }\end{array}$ & $\begin{array}{l}\text { Prep time } \\
\text { (hours) }\end{array}$ & $\begin{array}{l}\text { Statutory tax } \\
\text { rate }\end{array}$ & Tax base & $\begin{array}{l}\text { Total tax rate }(\% \\
\quad \text { of profit })\end{array}$ \\
\hline Corporate income tax & 1 & 155 & $25.5 \%$ & Taxable profit & $18.96 \%$ \\
\hline $\begin{array}{l}\text { Employer contribution to welfare pension } \\
\text { insurance }\end{array}$ & 0 & & $8.56 \%$ & Gross salaries & $9.61 \%$ \\
\hline Tokyo Metropolitan Enterprise Tax & 0 & & $9.10 \%$ & Taxable profit & $6.15 \%$ \\
\hline Employer contribution to health insurance & 1 & 140 & $4.985 \%$ & Gross salaries & $5.62 \%$ \\
\hline Inhabitants tax & 1 & & $\begin{array}{c}5.2785 \% \\
(+¥ 530,000)\end{array}$ & Taxable profit & $3.8 \%$ \\
\hline $\begin{array}{l}\text { Employer contribution to workmen's accident } \\
\text { insurance }\end{array}$ & 0 & & $1.9 \%$ & Gross salaries & $1.86 \%$ \\
\hline Tokyo City depreciable fixed assets tax & 1 & & $1.4 \%$ & $\begin{array}{l}\text { Net value of fixed } \\
\text { assets }\end{array}$ & $1.65 \%$ \\
\hline $\begin{array}{l}\text { Tokyo City fixed assets tax (on land and } \\
\text { building) }\end{array}$ & 1 & & $1.4 \%$ & Property value & $1.28 \%$ \\
\hline $\begin{array}{l}\text { Tokyo Metropolitan real property acquisition tax } \\
\text { (for building expansion) }\end{array}$ & 1 & & $4 \%$ & $\begin{array}{l}70 \% \text { of building } \\
\text { expansion value }\end{array}$ & $0.85 \%$ \\
\hline Employer contribution to employment insurance & 1 & & $0.85 \%$ & Gross salaries & $0.83 \%$ \\
\hline $\begin{array}{l}\text { Tokyo City city planning tax (on land and } \\
\text { building) }\end{array}$ & 0 & & $0.3 \%$ & Property value & $0.27 \%$ \\
\hline Employer contribution to child allowance & 0 & & $0.15 \%$ & Gross salaries & $0.17 \%$ \\
\hline
\end{tabular}




\begin{tabular}{|c|c|c|c|c|c|}
\hline Tax (contribution) & $\begin{array}{l}\text { Payments } \\
\text { (number) }\end{array}$ & $\begin{array}{l}\text { Prep time } \\
\text { (hours) }\end{array}$ & $\begin{array}{c}\text { Statutory tax } \\
\text { rate }\end{array}$ & Tax base & $\begin{array}{c}\text { Total tax rate (\% } \\
\text { of profit) }\end{array}$ \\
\hline Registration and license tax & 1 & & $0.4 \%$ & $\begin{array}{l}70 \% \text { of building } \\
\text { expansion value }\end{array}$ & $0.08 \%$ \\
\hline National stamp tax & 1 & & $¥ 125,000$ & Per contract & $0.05 \%$ \\
\hline Tokyo Metropolitan automobile tax & 1 & & $¥ 67,100$ & Fixed fee & $0.03 \%$ \\
\hline National automobile tonnage tax & 1 & & $¥ 41,600$ & Fixed fee & $0.02 \%$ \\
\hline Value added tax & 1 & 35 & $5 \%$ & Value added & \\
\hline Restoration surtax & 1 & & $2.55 \%$ & Taxable profits & \\
\hline Fuel tax & 1 & & $\begin{array}{l}¥ 34,140 \text { per } \\
\text { kiloliter }\end{array}$ & Fuel consumed & \\
\hline Tax on interest income & 0 & & $20.315 \%$ & Interest income & \\
\hline Total & 14 & 330 & & & $51.2 \%$ \\
\hline
\end{tabular}


Table A8. Documents, time, and costs associated with trading across borders in Tokyo

\begin{tabular}{|l|c|c|}
\hline Nature of Export Procedures & Duration (days) & US\$ Cost \\
\hline Documents preparation & 5 & 145 \\
\hline Customs clearance and inspections & 2 & 75 \\
\hline Ports and terminal handling & 2 & 250 \\
\hline Inland transportation and handling & 2 & 445 \\
\hline Totals & $\mathbf{1 1}$ & $\mathbf{9 1 5}$ \\
\hline
\end{tabular}

\begin{tabular}{|l|c|c|}
\hline Nature of Import Procedures & Duration (days) & US\$ Cost \\
\hline Documents preparation & 5 & 277 \\
\hline Customs clearance and inspections & 2 & 135 \\
\hline Ports and terminal handling & 2 & 250 \\
\hline Inland transportation and handling & 2 & 445 \\
\hline Totals & $\mathbf{1 1}$ & $\mathbf{1 , 1 0 7}$ \\
\hline
\end{tabular}

\begin{tabular}{|l|l|}
\hline Export documents & Import documents \\
\hline Bill of lading & Bill of lading \\
\hline Commercial Invoice & Cargo dispatch document \\
\hline Customs export declaration & Commercial invoice \\
\hline & Customs import declaration \\
\hline & Packing list \\
\hline
\end{tabular}

Table A9. Procedures, time, and costs associated with enforcing contracts in Tokyo

\begin{tabular}{|c|c|}
\hline Time (days) & 360 \\
\hline Filing and service & 20 \\
\hline Trial and judgment & 280 \\
\hline Enforcement of judgment & 60 \\
\hline Cost (\% of claim) & 32.2 \\
\hline Attorney cost (\% of claim) & 18.5 \\
\hline Court cost $(\%$ of claim $)$ & 13.3 \\
\hline Enforcement Cost (\% of claim) & 0.4 \\
\hline Procedures (number) & 32 \\
\hline
\end{tabular}


Table A10. The strengths and weaknesses in existing insolvency regulations in Tokyo

\begin{tabular}{|l|l|}
\hline Indicator & Score \\
\hline $\begin{array}{l}\text { The average duration of bankruptcy proceedings. The time of the proceedings is } \\
\text { recorded in calendar years and includes all appeals and delays. }\end{array}$ & 0.6 \\
\hline $\begin{array}{l}\text { The average cost of bankruptcy proceedings. The cost of the proceedings is } \\
\text { recorded as a percentage of the estate's value. }\end{array}$ & 3.5 \\
\hline $\begin{array}{l}\text { The recovery rate calculates how many cents on the dollar secured creditors } \\
\text { recover from an insolvent firm at the end of insolvency proceedings. }\end{array}$ & 92.9 \\
\hline $\begin{array}{l}\text { The index measures what type of proceedings (liquidation, reorganization or } \\
\text { both) debtors and creditors can initiate and what standard is used to declare a } \\
\text { debtor insolvent. }\end{array}$ & 3 \\
\hline $\begin{array}{l}\text { The index tests provisions on continuation and rejection of contracts during } \\
\text { insolvency, avoidance of preferential and undervalued transactions and post- } \\
\text { commencement credit. }\end{array}$ & 6 \\
\hline $\begin{array}{l}\text { The index measures whether and how creditors vote on a reorganization plan } \\
\text { and what protections are available to dissenting creditors. }\end{array}$ & 3 \\
\hline $\begin{array}{l}\text { The index tests creditors' participation in and rights during liquidation and } \\
\text { reorganization proceedings. }\end{array}$ & 2 \\
\hline $\begin{array}{l}\text { The index is the sum of four component indices: commencement of proceedings } \\
\text { index, management of debtor's assets index, reorganization proceedings index } \\
\text { and creditor participation index. }\end{array}$ & 14 \\
\hline Commencement of proceedings index (0-3) & 3.0 \\
\hline Management of debtor's assets index (0-6) & 6.0 \\
\hline Reorganization proceedings index (0-3) & 3.0 \\
\hline Creditor participation index (0-4) & 2.0 \\
\hline
\end{tabular}




\begin{tabular}{|c|c|c|c|}
\hline \\
\hline $\begin{array}{l}\text { What procedures are available to a DEBTOR when } \\
\text { commencing insolvency proceedings? }\end{array}$ & \multicolumn{3}{|c|}{$\begin{array}{l}\text { Debtor may file for both liquidation and } \\
\text { reorganization }\end{array}$} \\
\hline $\begin{array}{l}\text { Does the insolvency framework allow a creditor to file } \\
\text { for insolvency of the debtor? }\end{array}$ & \multicolumn{3}{|c|}{$\begin{array}{l}\text { Yes, a creditor may file for both } \\
\text { liquidation and reorganization }\end{array}$} \\
\hline $\begin{array}{l}\text { What basis for commencement of the insolvency } \\
\text { proceedings is allowed under the insolvency } \\
\text { framework? }\end{array}$ & \multicolumn{3}{|c|}{$\begin{array}{l}\text { Both (a) and (b) options are available, but } \\
\text { only one of them needs to be complied } \\
\text { with }\end{array}$} \\
\hline \multicolumn{2}{|c|}{ Management of debtor's assets index (0-6) } & \multicolumn{2}{|c|}{6.0} \\
\hline \multicolumn{2}{|c|}{$\begin{array}{l}\text { Does the insolvency framework allow the continuation of contracts } \\
\text { supplying essential goods and services to the debtor? }\end{array}$} & \multicolumn{2}{|l|}{ Yes } \\
\hline \multicolumn{2}{|c|}{$\begin{array}{l}\text { Does the insolvency framework allow the rejection by the debtor of } \\
\text { overly burdensome contracts? }\end{array}$} & \multicolumn{2}{|l|}{ Yes } \\
\hline \multicolumn{2}{|c|}{$\begin{array}{l}\text { Does the insolvency framework allow avoidance of preferential } \\
\text { transactions? }\end{array}$} & \multicolumn{2}{|l|}{ Yes } \\
\hline \multicolumn{2}{|c|}{$\begin{array}{l}\text { Does the insolvency framework allow avoidance of undervalued } \\
\text { transactions? }\end{array}$} & \multicolumn{2}{|l|}{ Yes } \\
\hline \multicolumn{2}{|c|}{$\begin{array}{l}\text { Does the insolvency framework provide for the possibility of the } \\
\text { debtor obtaining credit after commencement of insolvency } \\
\text { proceedings? }\end{array}$} & \multicolumn{2}{|l|}{ Yes } \\
\hline \multicolumn{2}{|c|}{$\begin{array}{l}\text { Does the insolvency framework assign priority to post- } \\
\text { commencement credit? }\end{array}$} & \multicolumn{2}{|c|}{$\begin{array}{l}\text { Yes over ordinary unsecured } \\
\text { creditors but not over } \\
\text { secured creditors }\end{array}$} \\
\hline \multicolumn{2}{|l|}{ Reorganization proceedings index $(0-3)$} & \multicolumn{2}{|l|}{3.0} \\
\hline \multicolumn{2}{|l|}{ Which creditors vote on the proposed reorganization plan? } & \multicolumn{2}{|c|}{$\begin{array}{l}\text { Only creditors whose rights are } \\
\text { affected by the proposed plan }\end{array}$} \\
\hline \multicolumn{2}{|c|}{$\begin{array}{l}\text { Does the insolvency framework require that dissenting creditors } \\
\text { in reorganization receive at least as much as what they would } \\
\text { obtain in a liquidation? }\end{array}$} & \multicolumn{2}{|l|}{ Yes } \\
\hline \multicolumn{2}{|c|}{$\begin{array}{l}\text { Are the creditors devided into classes for the purposes of voting } \\
\text { on the reorganization plan, does each class vote separately and } \\
\text { are creditors in the same class treated equally? }\end{array}$} & \multicolumn{2}{|l|}{ Yes } \\
\hline \multirow{2}{*}{\multicolumn{3}{|c|}{$\begin{array}{l}\text { Creditor participation index (0-4) } \\
\text { Does the insolvency framework require approval by the creditors for selection or } \\
\text { appointment of the insolvency representative? }\end{array}$}} & 2.0 \\
\hline & & & No \\
\hline \multicolumn{3}{|c|}{$\begin{array}{l}\text { Does the insolvency framework require approval by the creditors for sale of } \\
\text { substantial assets of the debtor? }\end{array}$} & No \\
\hline \multicolumn{3}{|c|}{$\begin{array}{l}\text { Does the insolvency framework provide that a creditor has the right to request } \\
\text { information from the insolvency representative? }\end{array}$} & Yes \\
\hline \multicolumn{3}{|c|}{$\begin{array}{l}\text { Does the insolvency framework provide that a creditor has the right to object to } \\
\text { decisions accepting or rejecting creditors' claims? }\end{array}$} & Yes \\
\hline
\end{tabular}




\section{Appendix 2. Expert Survey on Economic Reforms in Japan}

To gauge the extent of political challenges that each of the 31 reforms that we consider in this paper, we have conducted an expert survey. The survey was designed and conducted using the Qualtrics survey tool. The 31 reforms were grouped into three groups (reforms 1 through 10 , reforms 11 through 20, and reforms 21 through 31 ) and each respondent was randomly asked to answer the questionnaire for one of the three groups. ${ }^{34}$

The survey was sent to 68 political scientists who we consider are knowledgeable in Japanese politics. 23 of them received the questionnaire for reforms 1-10, 23 received the one for reforms 11-20, and 22 received the one for reforms 21-30. The emails asking to participate in the survey was sent out on July 14, 2015 and the recipients were asked to complete the survey by July 21. 27 respondents (10 for reforms 1-10, 10 for reforms 11-20, and 7 for reforms 21-31) answered at least one question. Many answered all the questions.

Emails were titled "Request for Assistance - Expert Survey on Economic Reforms in Japan" and started as:

I am working on a paper on one particular policy in the Abenomics growth strategy. Improving the environment for business is an important part of the growth strategy of Abenomics. As the KPI (Key Performance Indicator) for this effort, the Abe Administration aims to improve Japan's rank in the World Bank Doing Business Ranking from the \#15 (in 2013 Report) among OECD countries to one of the top three. The paper identifies several reforms that Japan can implement to improve its ranking.

I would like you to help us gauge the extent of political challenges each reform is likely to face by completing a brief survey. In this survey, we ask you to judge the extent of political resistances that the reform is likely to face using the following four point scale.

(1). The reform is expected to face low political resistance.

(2). The reform is expected to face somewhat low political resistance.

(3). The reform is expected to face somewhat high political resistance.

(4). The reform is expected to face high political resistance.

Each question also has a space where you can write in additional comments (optional).

To have an idea about "low" political resistance and "high" political resistance for policies, the following examples may be useful. As a part of "Cool Japan" strategy to promote Japanese contents (such as manga and anime) and food (washoku) industries, the government proposes establishment of a one-stop contact point for facilitating the rights management of content. You may judge that the political resistance for such policy is expected to be "low." On the other hand, you would judge that policies to promote TPP (Trans-Pacific Partnership) and other FTAs (Free Trade Agreements) are likely to face "high" political resistance because they will be opposed by powerful agricultural interest.

The survey will take 5-20 minutes to complete depends on how deeply you consider each question. If possible, I would like to get your response by Monday, July 20. I appreciate your help.

\footnotetext{
${ }^{34}$ We are grateful to Mary Shiratori for designing and conducting the survey. She also created spreadsheets of the survey result, which we used for the analysis. We thank Anil Kashyap, Kenji Kushida, Phillip Lipscy, Ulrike Schaede, and Paul Schuler for giving us comments to improve the survey instrument. We also thank the experts who responded to our survey: Daniel Aldrich, Marie Anchordoguy, Amy Catalinac, William Grimes, Yusaku Horiuchi, Saori Katada, Azusa Katagiri, Junko Kato, Ellis Krauss, Ikuo Kume, Kenneth MacElwain, Ko Maeda, Megumi Naoi, Gene Park, T.J. Pempel, Frances Rosenbluth, Richard Samuels, Ethan Scheiner, Kay Shimizu, Dan Smith, Yuki Takagi, Harukata Takenaka, Hiroki Takeuchi, Mark Tilton, Maria Toyoda, and Steve Vogel.
} 
Takeo Hoshi

Asia-Pacific Research Center, Stanford University

Then the email listed the link for the survey for one of the three groups of reforms.

The questionnaire for each of the three groups of reforms is reproduced below. The paragraph "Details" is shown only when the respondent clicks the "show details" button. For each question, the respondent can leave comments if (s)he chooses to do so.

\section{A2.1 Questionnaire for Reforms 1 through 10}

Reform 1: Eliminate the requirement for a company seal: This reform eliminates the requirement for an entrepreneur to make a company seal and register it. The cost for making a seal is about $¥ 10,000$ for machine-carved seal or $¥ 20,000$ for hand-carved seal. The entrepreneur or a company representative must register the company seal and obtain the certificate of seal registration from the Ward office in person. The certificate then must be submitted to the Legal Affairs Bureau at the Ministry of Justice. The fee is approximately $¥ 400$ per certificate of seal registration but varies from ward to ward.

Details: Currently, an entrepreneur is required to make a company seal and register it. These two procedures take about 4 days. The company seal is required, per Article 20 of the Commercial Registration Act. The requirement is a legacy of the old business practice where a seal symbolized the legal identity of a business and authenticated all its contracts. Seal makers (many of them very small business) may oppose to the reform.

What is the extent of political resistance that you expect for this reform?

(1). Low

(2). Somewhat low

(3). Somewhat high

(4). High

Comments (optional):

Reform 2: Make business registration administrative rather than judicial: Currently, to apply for registration, an entrepreneur submits a duly completed application form, along with supporting documents including the certificate of seal registration and the Articles of Incorporation to the Legal Affairs Bureau headquarter or any of its branch offices in major cities. Once the filed documents are reviewed and approved, the company applies for the issuance of a company registration certificate. Normally, a judicial scrivener completes the registration on behalf of the company. The whole process takes 4 days.

Details: Japan can reduce the time for business registration by making it a simple administrative process rather than judicial process. This seems to be straightforward. Similar reforms have been implemented in many countries less developed than Japan, including Serbia, Uganda, Bulgaria, and Honduras. It is hard to imagine prominent interest groups that would oppose to the reform.

What is the extent of political resistance that you expect for this reform?

(1). Low 
(2). Somewhat low

(3). Somewhat high

(4). High

Comments (optional):

Reform 3: Create one-stop shop for business registration: Currently, the eight procedures that must be completed to start a business in Japan require an entrepreneur to visit almost as many regulators including the Ward Office (to obtain the certificate of seal registration), Ministry of Justice, District Tax Office, Municipality, Labor Standards Inspection Office, Japan Pension Service, and Public Employment Security Office.

Details: Creating one-stop shops for company registration has been a popular reform over the last decade in many countries. For example, Portugal combined company, tax and social security registrations in one building. An obvious interest group that may object to such a reform includes bureaucrats who might view the reform as detrimental to their authority.

What is the extent of political resistance that you expect for this reform?

(1). Low

(2). Somewhat low

(3). Somewhat high

(4). High

Comments (optional):

Reform 4: Cut registration fees: This reform proposes to reduce the registration fee to $¥ 1,700$ regardless of the size of corporation. It currently costs $0.7 \%$ of the official stated capital or $¥ 60,000$, whichever is higher, to register the company at the Legal Affairs Bureau of the Ministry of Justice in Japan.

Details: Registration fees account for the bulk of the direct monetary cost to start a business in Japan. Ministry of Finance might object to the reform on the ground that this would reduce the government revenues.

What is the extent of political resistance that you expect for this reform?

(1). Low

(2). Somewhat low

(3). Somewhat high

(4). High

Comments (optional):

Reform 5: Reduce the number of procedures to get a construction permit: Currently a company must complete 12steps to build a warehouse legally. These procedures include acquiring permits/consents from local authority, neighborhood, Building Department of Government of Tokyo, Labor Control Office, Japan Building Center, and Land and Building Registry. Japan Building Center and the Local Authority account for 9 out of the 12 procedures. The reform proposes to cut the number of procedures to six by: 
(1) Combining two procedures to receive intermediate and final inspections from Japan Building Center, combining two procedures to obtain completion certificate and building permit from Japan Building Center.

(2) Combining the five procedures to hold initial consultation with local authority, obtain consent of neighborhood, purchase and post statutory construction notice sign board, submit construction method plan to local authority and obtain approval, and submit project safety and health and resources recycling plan to local authority and obtain approval. An entrepreneur should be able to do the above procedures in one visit to the local authority.

Details: Some of the 12 procedures to legally build a warehouse are redundant and can be merged with other ones. The Building Department of Government of Tokyo, Labor Control Office, Japan Building Center, and Land and Building Registry may object this reform as they may view it as detrimental to their authority.

What is the extent of political resistance that you expect for this reform?

(1). Low

(2). Somewhat low

(3). Somewhat high

(4). High

Comments (optional):

Reform 6: Reduce the time to issue a construction permit: This reform proposes to limit the time it takes to issue a permit to 67 days (cutting 130 days from the current 197 days). The government can introduce "silence is consent" rules: if the permit is not issued within the timeline the construction is considered being approved. Also, the government can scale back inspections for small construction projects. Such reform would adjust inspections to the size and nature of the project.

Details: The Japan Building Center, Labor Control Office, and Water and Sewage Services may object this reform; these institutions account for the bulk of time required to deal with construction permits.

What is the extent of political resistance that you expect for this reform?

(1). Low

(2). Somewhat low

(3). Somewhat high

(4). High

Comments (optional):

Reform 7: Reduce the number of days it takes for getting electricity by 80 days by improving process efficiency: After an initial contact with TEPCO on construction date and effective date of contract, it currentlytakes 93 days before electricity connection works start. After an average of 93 days of waiting, TEPCO takes 11 more days to carry out connection works and install a meter. In this reform, the government would convince TEPCO to respond more quickly to the customers' request to start electricity services. 
Details: Examples from the rest of the world show that it is possible to increase the efficiency of utilities' internal processes and reduce the electricity connection delays. TEPCO may object to this reform because it would need to make efforts to increase efficiency.

What is the extent of political resistance that you expect for this reform?

(1). Low

(2). Somewhat low

(3). Somewhat high

(4). High

Comments (optional):

Reform 8: Reduce the time to register property by introducing fast-track procedures: The reform proposes to let the Legal Affairs Bureau offer a choice of expedited procedures: pay a slightly higher fee and the registration is completed in 1-2 days instead of the current practice of 7-10 days.

Details: The Legal Affairs Bureau registers the title under the name of the new owner. As registration is a requirement for perfection against third parties, reviewing the certified copy of the real property registry is generally sufficient for identifying any existing encumbrances over the real property. The parties may apply for registration by themselves. However, because of the complexity of filing, usually they retain a judicial scribe for registration. The Legal Affairs Bureau may be in need of some structural reforms to reduce their respective delays but such reforms might require long-term efforts. It is hard to imagine prominent interest groups that would oppose to the reform.

What is the extent of political resistance that you expect for this reform?

(1). Low

(2). Somewhat low

(3). Somewhat high

(4). High

Comments (optional):

Reform 9: Combine and eliminate some procedures for registering property: The reform combines two procedures that the seller of the property needs to complete (obtaining a corporate registry certificate and obtaining a certificate of its official seal) into one. The reform also eliminates the requirement to pay stamp duty at a post office.

Details: The corporate registry office and the Legal Affairs Bureau may oppose this reform.

What is the extent of political resistance that you expect for this reform?

(1). Low

(2). Somewhat low

(3). Somewhat high

(4). High

Comments (optional): 
Reform 10: Lower property registration fees: Currently, an entrepreneur in Tokyo must pay a registration and license tax of $1.75 \%$ of property value and a property acquisition tax of $4 \%$ of property value. The reform replaces these fees with single fee of $0.1 \%$ of property value.

Details: The cost to register property could be reduced significantly by replacing the current percentage-based taxes by a fixed fee. Ministry of Finance might object to the reform on the ground that this would reduce the government revenues.

What is the extent of political resistance that you expect for this reform?

(1). Low

(2). Somewhat low

(3). Somewhat high

(4). High

Comments (optional):

\section{A2.2 Questionnaire for Reforms 11 through 20}

Reform 11: Create a unified legal framework for secured transactions including creation, publicity and enforcement of security interests in movable assets: This reform would improve collateral laws to make it easier for businesses to use their assets, especially movables, to secure credits. The businesses will be allowed to grant a non-possessory security right in a single category of movable assets (such as "machinery" or "inventory") without requiring a specific description of the collateral. Security right will also extend to future or after-acquired assets and to the products, proceeds or replacements of original assets automatically.

Details: Japan can allow the businesses to grant a non-possessory security right in a single category of movable assets (such as "machinery" or "inventory") without requiring a specific description of the collateral. This reform would increase the strength of legal rights of creditors but may face objection from some borrowers.

What is the extent of political resistance that you expect for this reform?

(1). Low

(2). Somewhat low

(3). Somewhat high

(4). High

Comments (optional):

Reform 12: Create a collateral registry in which all functional equivalents can be registered: All functional equivalents to security interests in movable assets (fiduciary transfer of title, financial leases, assignment or transfer of receivables, and sales with retention of title) will be registered. The collateral registry will cover both incorporated and non-incorporated businesses, unified geographically, and with an electronic database indexed by debtor's names. The collateral registry will also allow secured creditors to register, search, amend or cancel security interests online. 
Details: Japan can improve the system of registering collaterals by creating a collateral registry in which all functional equivalents to security interests in movable assets (fiduciary transfer of title, financial leases, assignment or transfer of receivables, and sales with retention of title) are recorded. If the reform is viewed as additional regulatory burdens for reporting, there may be some objections from the financial industry.

What is the extent of political resistance that you expect for this reform?

(1). Low

(2). Somewhat low

(3). Somewhat high

(4). High

Comments (optional):

Reform 13: Reform bankruptcy law: This reform introduces automatic stay for creditors in court-supervised reorganizations (Corporate Reorganization and Civil Rehabilitation). The reform also allows secured creditors to be paid first even before tax claims and employee claims when a business is liquidated.

Details: Japan can improve the security rights of lenders in court-supervised restructuring by changing the bankruptcy law. It can also allow secured creditors to be paid first even before tax claims and employee claims when a business is liquidated. This reform may face challenges from Ministry of Justice as it favors a less active judicial involvement in the proceedings and is based on the principle that more control of the proceedings should lie in the hands of the creditors. It is a hurdle to convince judges to relinquish some of their power while maintaining their role as guarantor of the fairness of the proceedings not only in liquidation procedures but also in reorganization procedures.

What is the extent of political resistance that you expect for this reform?

(1). Low

(2). Somewhat low

(3). Somewhat high

(4). High

Comments (optional):

Reform 14: Establish a public credit registry for corporations: Currently Japan has private sector credit bureaus that collect and distribute credit information on individuals, but does not have those for credit information of corporations. In this reform, the government creates a public credit registry that collects and distributes credit information on corporations.

Details: Japan has private sector credit bureaus that collect and distribute credit information on individuals, but does not have those for credit information of corporations. To fill the gap, the government can create a public credit registry that collects and distributes credit information on corporations. The corporate sector may object this reform for reasons related to data security, retention, and privacy as well as for compliance matters and actions in the event of noncompliance. 
What is the extent of political resistance that you expect for this reform?

(1). Low

(2). Somewhat low

(3). Somewhat high

(4). High

Comments (optional):

Reform 15: Increase disclosure requirements: The reform includes three changes in the Corporate Law. First, it requires a resolution at both a board meeting and a general shareholders meeting to approve business transactions that entail a conflict of interest of a director and majority shareholders. Currently a resolution at the board level is sufficient. Second, a review by an external body for such transaction will be required before it takes place. Third, companies will be required to disclose any transaction that entails a conflict of interest immediately to the public and shareholders.

Details: By implementing three reforms, Japan can improve the extent of disclosure requirements. First, Japan can require a resolution at both a board meeting and a general shareholders meeting to approve business transactions that entail a conflict of interest of a director and majority shareholders. Currently are solution at the board level is sufficient. Second, a review by an external body for such transaction can be required before it takes place. Third, Japan can require immediate disclosure, to the public and/or shareholders, of transactions that entail a conflict of interest. Large incumbent shareholders may be opponents for such reform as it entails increased financial disclosure and requires a company to report large transactions with a controlling shareholder immediately to the marketplace and in the annual report.

What is the extent of political resistance that you expect for this reform?

(1). Low

(2). Somewhat low

(3). Somewhat high

(4). High

Comments (optional):

Reform 16: Increase directors' liability: This reform includes three legal changes to increase the liability for corporate directors. First, directors are required to pay the damages caused to the company and also repay the profit made from self-dealing. Second, a director at fault can be punished by fines and imprisonment. Finally, the judicial system is allowed to void a business transaction if the transaction is deemed unfair to minority shareholders or entails a conflict of interest.

Details: By implementing three reforms, Japan can improve the extent of director liability. First, Japan can give the judicial system the power to void a business transaction if the transaction is deemed unfair to minority shareholders or entails a conflict of interest. Second, directors can be required to pay the damages caused to the company and also repay the profit made from selfdealing. Third, a director at fault can be punished by fines and imprisonment. Directors on corporate boards are obviously a potential group that would oppose to this reform. 
What is the extent of political resistance that you expect for this reform?

(1). Low

(2). Somewhat low

(3). Somewhat high

(4). High

Comments (optional):

Reform 17: Allow the plaintiff of a shareholder suit to request categories of documents without identifying specific ones: This reform makes it easier to minority shareholders to start a shareholder lawsuit.

Details: Currently the plaintiff of a shareholder lawsuit has to request specific documents in order to see those.

What is the extent of political resistance that you expect for this reform?

(1). Low

(2). Somewhat low

(3). Somewhat high

(4). High

Comments (optional):

Reform 18: Strengthen governance structure: The reform includes four reforms of corporate governance. First, CEOs are prohibited from also serving as chairs of the board of directors. Second, companies are required to have separate audit committees. Third, a potential acquirer must make a tender offer to all shareholders upon acquiring $50 \%$ of a company. Fourth, crossshareholding between 2 independent companies are limited to 10\% of outstanding shares.

Details: Incumbent large shareholders and incumbent managers of traditional companies may oppose to the reform.

What is the extent of political resistance that you expect for this reform?

(1). Low

(2). Somewhat low

(3). Somewhat high

(4). High

Comments (optional):

Reform 19: Enhance corporate transparency: This includes two changes. First, corporations are required to disclose any ownership stakes representing $10 \%$ or more. Second, they are required to disclose the compensation of individual managers.

Details: Again, incumbent large shareholders and incumbent managers of traditional companies may oppose to the reform.

What is the extent of political resistance that you expect for this reform?

(1). Low 
(2). Somewhat low

(3). Somewhat high

(4). High

Comments (optional):

Reform 20: Improve shareholder rights: Two changes are included in this reform. First, shareholders will be allowed to amend company bylaws or statutes with a simple majority. Second, shareholders will be granted subscription rights on new shares automatically.

Details: Again, incumbent large shareholders and incumbent managers of traditional companies may oppose to the reform.

What is the extent of political resistance that you expect for this reform?

(1). Low

(2). Somewhat low

(3). Somewhat high

(4). High

Comments (optional):

\section{A2.3 Questionnaire for Reforms 21 through 31}

Reform 21: Reduce number of payments: Currently a company in Tokyo needs to make 14 payments (corporate income tax, social security contribution, value added tax, fuel tax, inhabitants tax, a depreciable fixed assets tax, a fixed assets tax on land and building, employer paid employment and health insurance premia, real property acquisition tax, business premises tax, stamp tax, registration and license tax, automobile tax, and automobile tonnage tax). The reform combines collections of these taxes so that a company has to make just 4 payments a year. The Tax Agency then distributes the revenues to other government agencies that used to receive revenues from these taxes.

Details: Some of these tax revenues are tied to specific public expenditures. For example, fuel tax and automobile tonnage tax are still used primarily to finance the expenditures on maintaining roads, although there have been some reforms to allow the government to use at least a part of those tax revenues for general expenditures. Some politicians may fear this reform is used to erode the funding for their preferred expenditures and may oppose to the reform. Moreover, these tax revenues go to different governments. Some are revenues to the central government and some others are for local governments. Local government may fear this reform would end up reducing their tax revenues and may oppose the reform.

What is the extent of political resistance that you expect for this reform?

(1). Low

(2). Somewhat low

(3). Somewhat high

(4). High

Comments (optional): 
Reform 22: Reduce corporate profit tax rate: The effective total tax rate (as \% of profit) is $51.3 \%$ in Japan. The reform eventually reduces this to $34 \%$.

Details: Ministry of Finance would worry that this would reduce the government revenues.

What is the extent of political resistance that you expect for this reform?

(1). Low

(2). Somewhat low

(3). Somewhat high

(4). High

Comments (optional):

Reform 23: Allow electronic submission and processing: The reform will use the newest webbased systems to allow exporters and importers to submit their documents from anywhere and to pay duties online.

Details: Customs administration may object to the reform which would require them to update their regulatory framework and invest in new information technologies.

What is the extent of political resistance that you expect for this reform?

(1). Low

(2). Somewhat low

(3). Somewhat high

(4). High

Comments (optional):

Reform 24: Link agencies through an electronic single window: This reform will link all agencies involved in trade and transportation through an electronic single-window system. Such a system will allow traders to file standard information and documents through a single entry point to fulfill all import, export and transit-related regulatory requirements, and to share relevant information with all parties involved including private participants such as banks and insurance companies as well as public agencies such as immigration and vehicle registration authorities.

Details: Customs administration may hinder this reform which would require developing information sharing system through a single entry point to fulfill all import, export and transitrelated regulatory requirements.

What is the extent of political resistance that you expect for this reform?

(1). Low

(2). Somewhat low

(3). Somewhat high

(4). High

Comments (optional): 
Reform 25: Use risk-based inspections: The reform will develop a system for establishing risk profiles of products(exports or imports) that enables adjusting the extent of inspections according to the potential risk.

Details: Ministry of Finance may object this reform which requires investments in equipment (i.e. scanners) to help expedite the processing of cargo.

What is the extent of political resistance that you expect for this reform?

(1). Low

(2). Somewhat low

(3). Somewhat high

(4). High

Comments (optional):

Reform 26: Improve transparency in trade regulation: The reform provides easy access to documentation of requirements and tariff schedules to reduce transactions costs for importers and exporters.

Details: Providing easy access to documentation of requirements and tariff schedules can reduce transactions costs for importers and exporters. The average customs clearance cost for exports is $25.3 \%$ lower in those economies where documentation requirements are easily accessible. Customs may hinder this reform as it requires efforts from their ends.

What is the extent of political resistance that you expect for this reform?

(1). Low

(2). Somewhat low

(3). Somewhat high

(4). High

Comments (optional):

Reform 27: Limit adjournments and make enforcement of judgments more efficient: Currently frequent adjournments slow down contract enforcements. Adjournments are responsible for 280 days out of the 360 days that it takes to get trial and a judgment. This reform limits the number of adjournments to one and reduce the time it takes to get trial and a judgment to 70 .

Details: Courts and judges may resist this reform as they may prefer longer time to make judgments.

What is the extent of political resistance that you expect for this reform?

(1). Low

(2). Somewhat low

(3). Somewhat high

(4). High

Comments (optional): 
Reform 28: Introduce performance measures for judges: The reform introduces performance evaluation for judges. The disposition rate (number of disposed cases divided by the number of incoming cases) can be used as a measure of performance.

Details: Judges may see this reform as introducing competition with peers and may resist the reform.

What is the extent of political resistance that you expect for this reform?

(1). Low

(2). Somewhat low

(3). Somewhat high

(4). High

Comments (optional):

Reform 29: Maintain specialized commercial court: The reform creates a stand-alone commercial court that specialize in handling business disputes.

Details: Judges may object this reform if creation of specialized court require them to change the practices. For example, commercial courts in many countries permit oral arguments and generally have less formal procedures compared to the general courts, which require written procedures.

What is the extent of political resistance that you expect for this reform?

(1). Low

(2). Somewhat low

(3). Somewhat high

(4). High

Comments (optional):

Reform 30: Expand case management systems and automation: This reform expands the use of case management that currently exists in minimal form and only in limited number of courts. Judicial case management involves monitoring and managing cases in the court docket from the filing of the claim until judgment is rendered. By analyzing court workloads, case management systems can help predict trends and allocate resources strategically.

Details: Judges and court officers may resist this reform as it may require changes in practices that they are used to and may need them to learn to use new tools (such as electronic filing, case tracking, document management, deadline reminders and scheduling of hearings).

What is the extent of political resistance that you expect for this reform?

(1). Low

(2). Somewhat low

(3). Somewhat high

(4). High

Comments (optional): 
Reform 31: Promote specialized courts: This reform creates courts specialized in insolvency cases.

Details: Ministry of Justice may object to this reform as it may require organizational and bureaucratic changes within the judicial system.

What is the extent of political resistance that you expect for this reform?

(1). Low

(2). Somewhat low

(3). Somewhat high

(4). High

Comments (optional): 